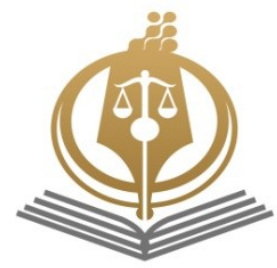

Interdisciplinary Legal Research

Apr 2020, 1(1): 13-30

Available online on: www. ilrjournal.ir

e-ISSN:2717-1795

ORIGINAL RESEARCH PAPER

\title{
The Effect of Architecture on Offences and Social Deviances
}

Received:

21 Mar 2020

Revised:

26 Mar 2020

Accepted:

29 Mar2020

Available Online:

01 Apr 2020

Mohammad Reza Rahmat ${ }^{1}$ *

Keywords:

House,

Architecture,

Law,

Color,

Psychology.

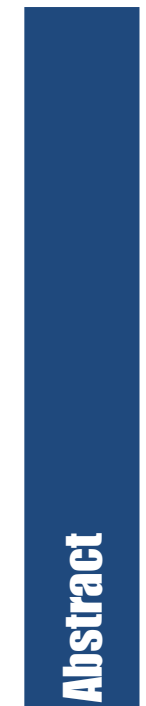

Background and Aim: House as the main position of the family, is of vital importance to the survival of the human and society. Nowadays, architects have discovered that the physical space is exactly the same as law can strengthen norms. The power of architecture in the expression of norms should not be underestimated.

Materials and Methods: The method of the present study is descriptive analytical one.

Ethical Considerations: Honesty and confidentiality have been observed.

Findings: Architectural engineers can create spaces that can move people close or away from each other. They can also enhance the feeling of security and comfort, or to add to the crowds and the psychosis of the community. The type and form of housing, factors and design methods also affect people's behavior.

The kind of life environment such as residence in dwellings or social housing has different social and cultural impacts. Also, two factors such as residence in rural areas as well as expanse of houses affect many residents ' behaviors. Psychological research shows the effect of design and map on behavior and perspectives. When people feel more space, they tend to be less aggressive. Today, the optimum use of factors such as nature, greenbelt and appropriate color reduces aggressive behavior. The color is another aspect of the city's life. Psychologists say that different colors affect behavior and emotions. Colors in people create different emotions and architects can use this feature to design residential environments.

Conclusion: Architecture is of great importance in commiting offences and social deviances.

\footnotetext{
1 * Assistant Professor of Law, University of Meybod, Yazd, Iran.
}

Email:Rahmat@Meybod.ac.ir Phone: +989124244752

Please Cite This Article As: Rahmat, MR (2020). "The Effect of Architecture on Offences and Social Deviances". Interdisciplinary Legal Research, 1 (1): 13-30. 
مقاله بروهشى

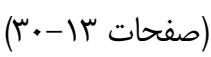

\section{تاثير معمارى بر وقوع جرايم و انحرافات اجتماعى}

\section{محمدرضا رحمت'}

I. استاديار، گروه حقوق، دانشگاه ميبد، يزد، ايران. Meybod.ac.ir: Rahmat@Meyil

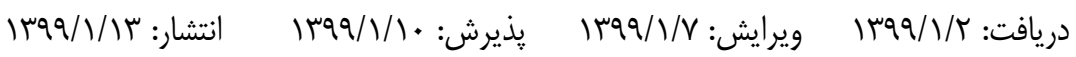

زمينه و هدف: مسكن به عنوان جايكاه اصلى خانواده، براى بقاى انسان و جامعه از اهميت بهسزايى برخوردار است. امروزه معماران به اين موضوع

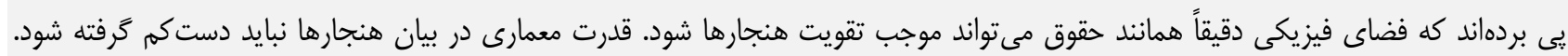
مواد و روشها: يزوهش حاضر با رويكرد توصيفى -تحليلى انجام شده است. ملاحظات اخلاقى: در به سامان رسيدن اين تحقيق ضمن رعايت اصالت متون، صداقت و امانتدارى رعايت شده است. يافتها: مهندسان معمارى مى توانند فضاهايى ايجاد كنند كه مردم را به هم نزديك يا از هم دور كنند. همجنين مى توانند احساس امنيت و راحتى را تقويت كرده، يا اينكه بر شلوغى و روانيريشى افراد اجتماع بيافزايند. نوع و شكل مسكن، عوامل و شيوههاى طراحى نيز در رفتار افراد تاثيركذار

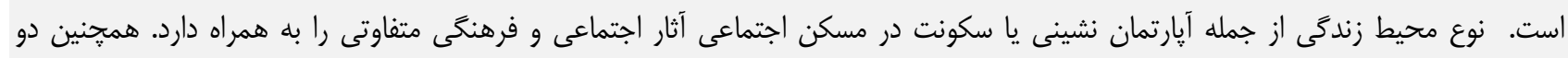

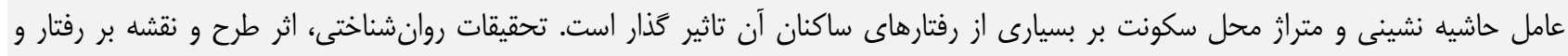

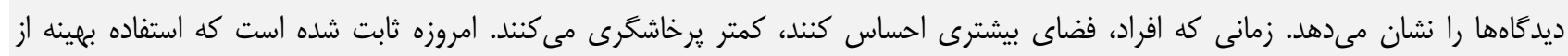

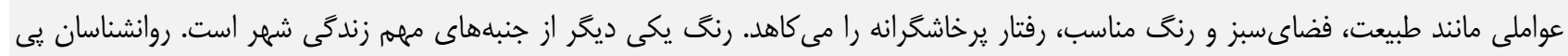

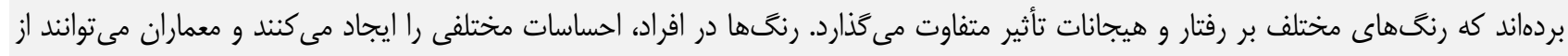
اين ويزگى براى طراحى محيطهاى مسكونى استفاده نمايند.

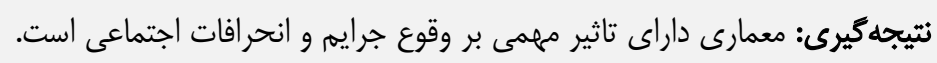
كلمات كليدى: مسكن، معمارى، حقوق، رنغ، روانشناسى. 
هنجارهاى اجتماعى، ابزار كاملى نيست و در بسيارى از موارد

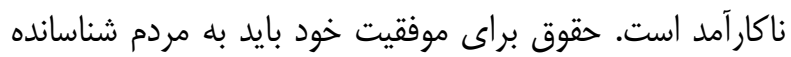
شود. در واقع مردم بايد حقوق را بدانند و به آن يايبند كردند. اما

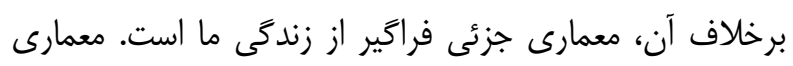

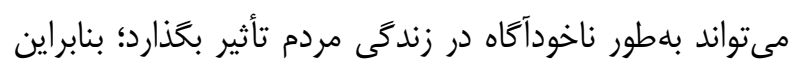
نياز به معرفى و شناسانده شدن به مردم را ندارد. مهندسان معمارى مىتوانند فضاهايى ايجاد كنند كه مردم را به هم به له

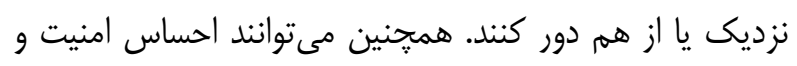
راحتى را تقويت كرده، يا اينكه بر شلوغى و روانيريشى افراد

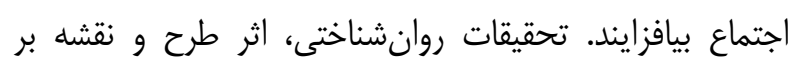

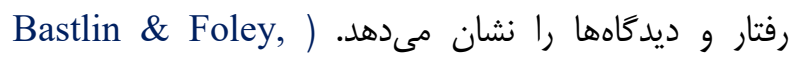

(1988: 56

در حوزه روانشناسى محيطى، در مورد اينكه خجكونه معمارى مىتواند تمايلات انسان را شكل دهد، بحثهاى زيادى صورت مورت مورد كرفته است. در اين حوزه ويزگَىهايى كه به صورت آَاهانه يا

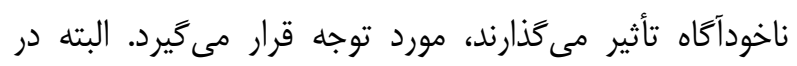

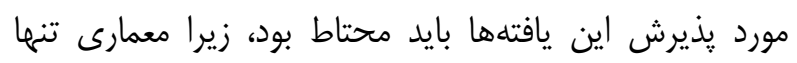

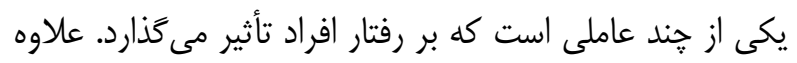
بر تعامل اجتماعى تأثيركذار، معمارى بر رفتار و ديدكاهها نيز

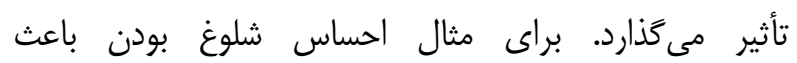

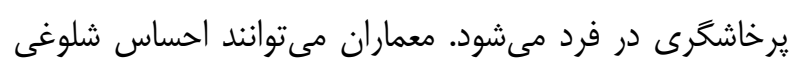

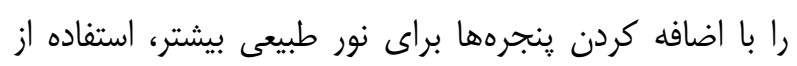

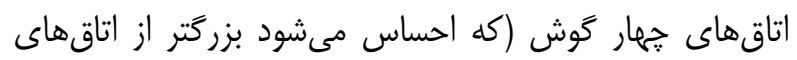

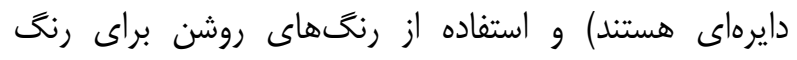

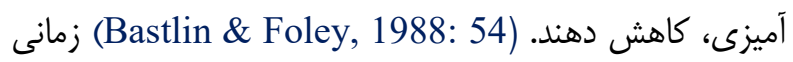
كه افراد، فضاى بيشترى احساس كنند، كمتر يرخاشگرى مى دهن كنند. امروزه ثابت شده است كه استفاده بهينه از عواملى مانند

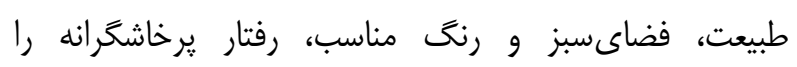

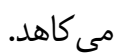
روانشناسان بِىبردهاند كه رنغَهاى مختلف بر رفتار و هيجانات تأثير متفاوت مى خذارد. به عنوان مثال، رنح قرمز موجب ميزان بنان

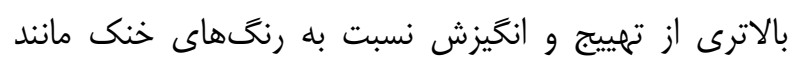
سبز و آبى مىشود. مطالعه ديخرى نشان مىدهد كه افراد در

\section{مقدمه}

1- بيان موضوع: از اساسىترين نيازهاى زيستى انسان بعد از

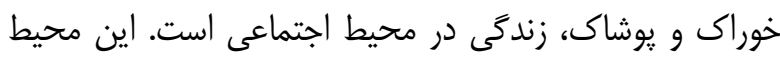

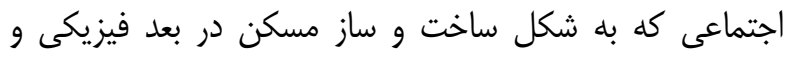

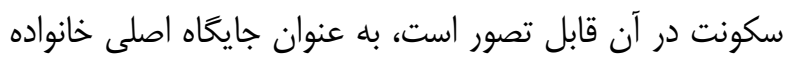
براى بقاى انسان و جامعه از اهميت بلهزايى برخوردار است. وقتى مجموعهاى مسكونى ساخته مى شود در واقع يك كانون اجتماعى شكل مى گيرد. اين كانون اجتماعى براى حفظ ارزش ماته

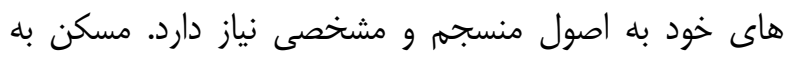
عنوان يك نياز انسان و يديده اجتماعى به سهرم خود، داراى ارتباطات متقابل با رفتار و فرهنگ انسانى است.

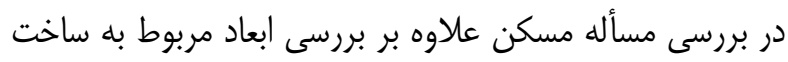

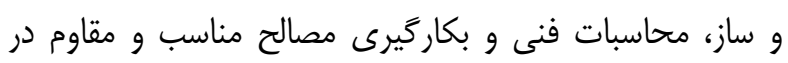

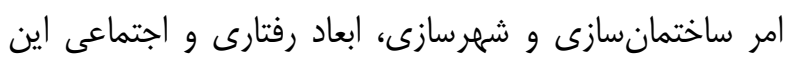

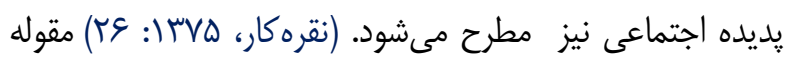

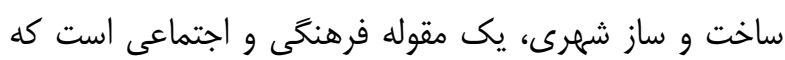
ريشه در فرهنگ گذنشته هر سرزمين داشته و نشانكر نحوه

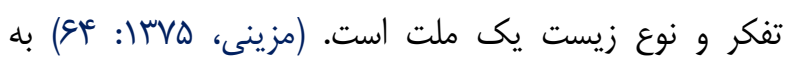
عبارت ديخر، معمارى هر جامعله در هر دوره از تاريخ، تبلور ويثگى هاى فرهنگیى، اجتماعى، اقتصادى حاكم بر آن جامعه و

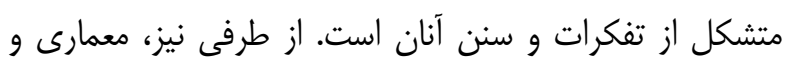

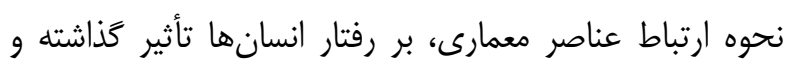

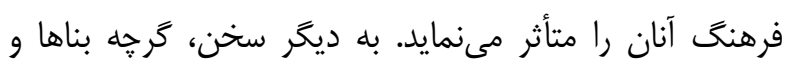
فضاها ساخته دست بشر است، ولى خود نيز بر رفتار اجتماعى و فردى آنان اثر مى گذارد.

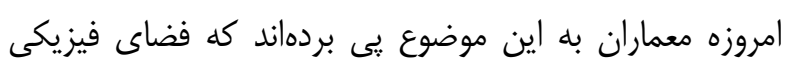
دقيقاً همانند حقوق مىتواند موجب تقويت هنجارها شود. مطالعه معمارى نشان مىدهد كه قواعد حقوقى، تنها ابزار بيان

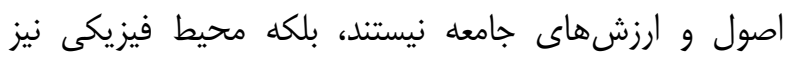

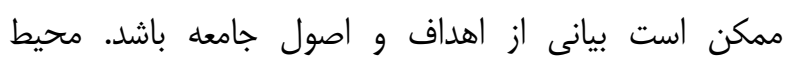
فيزيكى مى تواند بدون واسطه با هر كسى كه آن آن را مشاهده

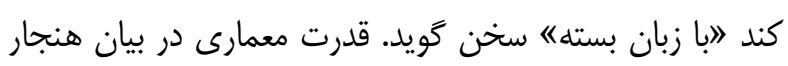

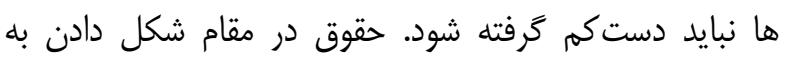


مجرمانه و روشهاى ييشخَيرى از وقوع جرم در مباحث طراحى بهره جست. در ادامه، عوامل به كار رفته در طراحى از قبيل رنغ، نور و طراحى منظر و تأثيرات رفتارى آن مورد بررسى بهى قرارمى گيرد. بديهى است ملحوظ داشتن اين عوامل و استفاده

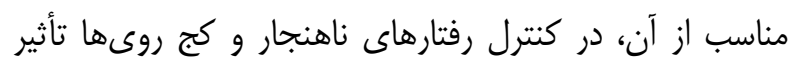
بلمسز ايى دارد. r- روش تحقيق: روش تحقيق در اين يزوهش بلهصورت تحليلى و توصيفى است.

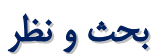

\section{ا - تاثير محيط بر رفتار: مكانهاى مختلف مسكونى}

معمارى نمود واقعى خود را در اماكن مسكونى (كه انسان

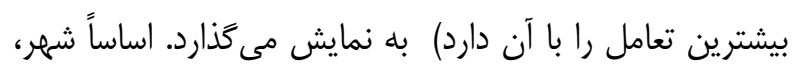

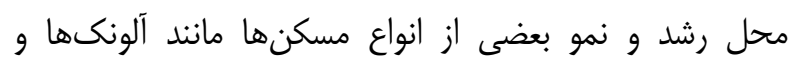

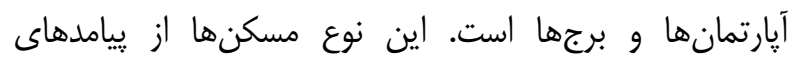

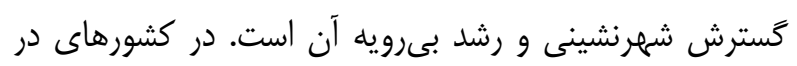

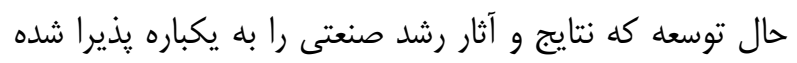

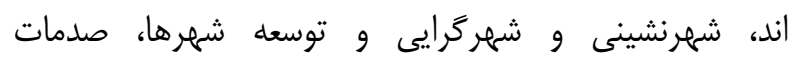
جبراننايذيرى بر رفتار مردم آن جامعله وارد كرده است. اين رشد شتابان و ناهمخون جمعيت (Desor, 1972: 79) شهرنشين، زمينه را جهت كمبود مسكن و شكل هاى نابهنجار فراهم نموده است و به دنبال خود تضعيف روابط ريط رئن حاكم بر نظام اجتماعى و بروز اختلالات رفتارى را به ارمغان

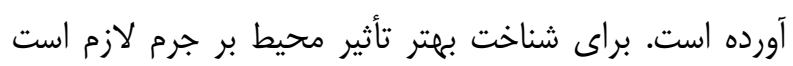

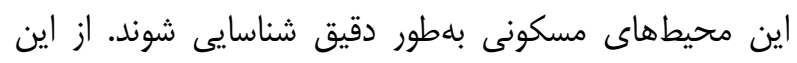
نوع سكونتخاهها مىتوان به خانههاى آيارتمانى، آلونكها،

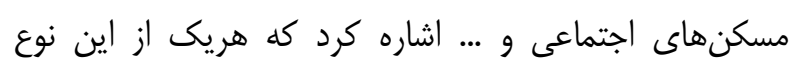
مسكنها مسائل فرهنكى و رفتارى خاص خود راعن ادارد. ا-1- آيارتماننشينى 1-1-1- طرح بحث. يكى از طرحهايى كه براى ياسخكَويى به

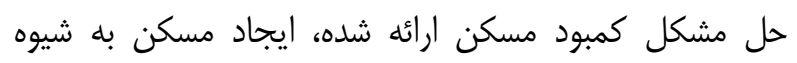

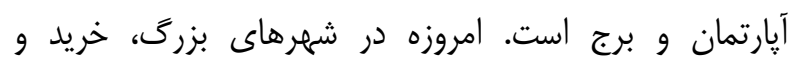
بازسازى ساختمانهاى قديمى و تبديل آن به صورت آيارتمان

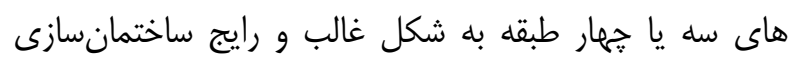

راهروهايى كه به رنغ قرمز يا نارنجى هستند، نسبت به افرادى

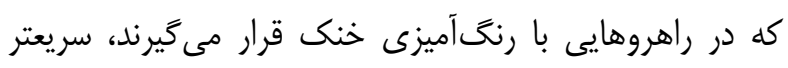

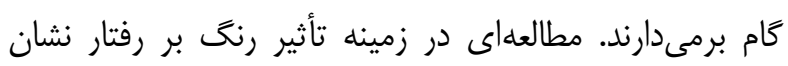

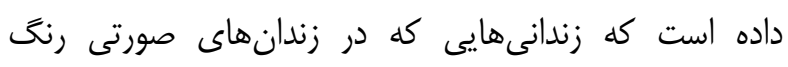
محبوس هستند نسبت به زندانىهاى ديخر كمتر باعث اغتشاش مىشوند. (Bastlin \& Foley, 1988: 56) در شش دهایى كه از عمر روانشناسى محيط مى تذرد،

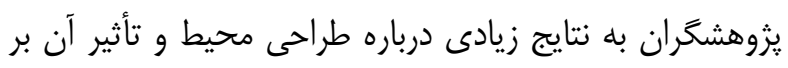
رفتار انسان دست يافتهاند. انسان محصول محيط، بيولوزى ورئاره

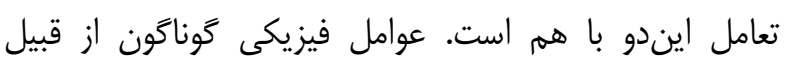

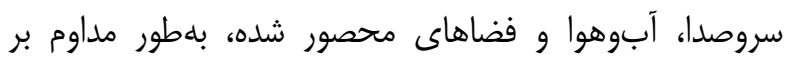

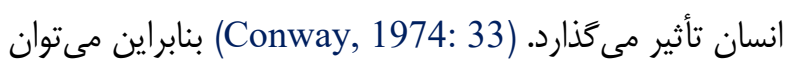
محيط را يكى از عواملى دانست كه نقش بسيار تعيين كنندهاى در شكل حوزه محيط و رفتار به صورت عام و رفتارهاى مجرمانه به دانه صورت خاص، برآيند جند رشته است. از اين رشتهها مىتوان به وحته

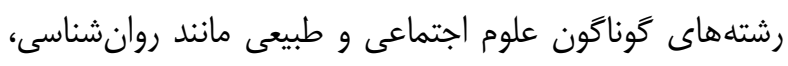

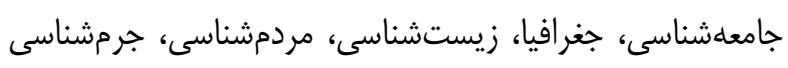

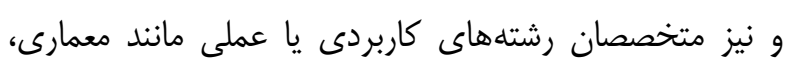

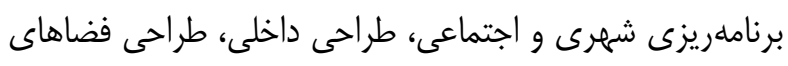

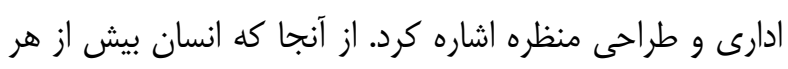
موجود ديخرى محيط خود را تغيير مى دهد و مىتواند با استفاده از اصول طراحى همجون زيبايىشناسى، مهندسى و هماهنگ

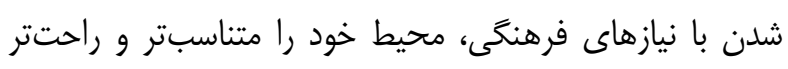
بسازد، (Edney, 1972: 128) با شناخت تأثير محيط بر انسان و استفاده از علوم مختلف، مىتوان اقدام به طراحى مناسب كرد. در اين نوشتار برآنيم تا به بحث درباره تأثير محيط و و به آله

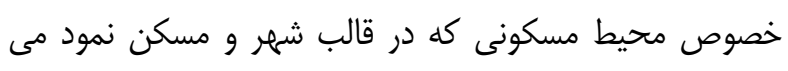
يابد، بر رفتار انسان كه در سطح عامترى نسبت به مهن رفتارهاى

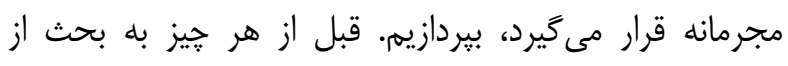
مكانهاى مختلف مسكونى در شهر يرداخته و تأثيرات رفتارى

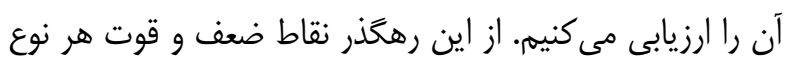

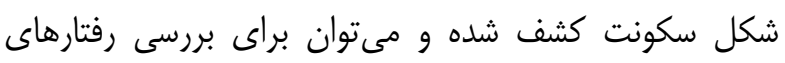


ساكنان خود را، اگر خه از نظر مكانى به هم نزديكاند، دامن زده و از نظر روحى و روانى آنها را از هم دور نمودهاند. (توسلى، لهان

سمسا: (घ)

مسائل مربوط به مخارج مشترى ساختمان و نظافت و و نكَهدارى آنها يكى ديخر از مشكلات است. يِيشرفت فن آورى اين امكان را مىدهد كه ستونهاى بنا، استحكام لازم جهت نخمهدارى كل ساختمان را داشته باشد، ولى وجود ديوارهاى كاذب، سر و صداى واحد مسكونى را به يكديخر منتقل مى كند و هر واحد از اتفاقاتى كه در واحد همجوارش مى افتد به وضوح

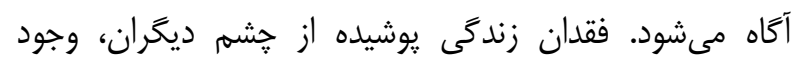
فرهنَ هاى متفاوت و اقشار گَوناگونى كه از نظر ذوق و سليقه،

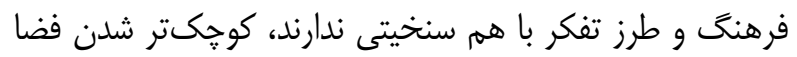

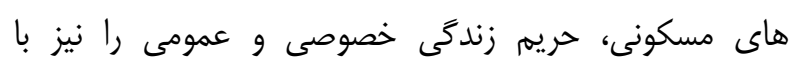

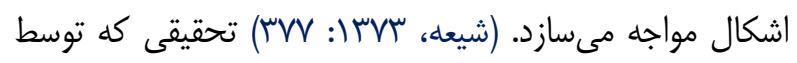

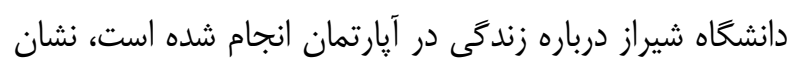
مى دهد كه اكثر ياسخ كَيان كه در خانههاى آيارتمانى سكونت داشتند، خانههاى تكى واحدى را بهتر از آيارتمانى مىداند آندان. همجنين نظر ساكنين آيارتمانهاى مورد بررسى اين بوده كه

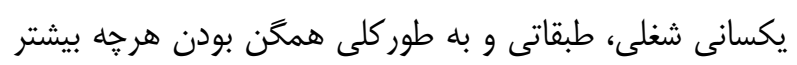
ساكنين، سبب آرامش محيط واحدها مىشود. (سيفالدينى،

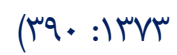

ו-ו-r- آيارتماننشينى: مسائل فرهنكى و رفتارى در يك بررسى اجمالى از مجموع مطالب ييشين مىتوان مسائل و مشكلات فرهنگى و رفتارى شهركىهاى آيارتمانى (عمودى) را به قرار ذيل دستهبندى نمود:

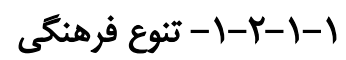

ساكنان آيارتمانها عمدتاً از مهاجران روستاها وهنا و شهرهاى

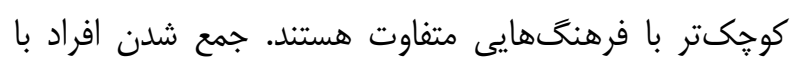
سطح فرهنگ و ديدگاههاى مختلف در يك مجموعه كه در موارد متعددى ناگزير از داشتن رابطهاند باعث ايجاد تنوع فرهنگى شده است. اين تنوع فرهنگى در بسيارى از موارد باعث ايجاد اصطكاك ميان افراد يك مجتمع مسكونى مى شود.
درآمده است. شكل افراطى ڤِيده آيارتمانسازى، احداث برج

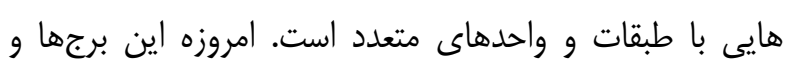
آيارتمان هاى بيىدريى، جهره شهرها را متحول ساخته است. مزيت عمده اين شكل سكونت آن است كه مقدار زيادى از از جمعيت را در كمترين مساحت و فضا و در قالب طبقات متعدد و واحدهاى سكونتى انبوه، در خود جاى مىدهد، امرى كه شايد

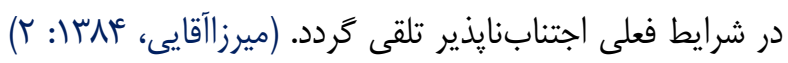
بلهور بالقوه، در بسيارى از موارد اين شكل سكونت با طراحى و نحوه ساخت و ساز خاص خود، تناسبى با روابط متراكم انسانى

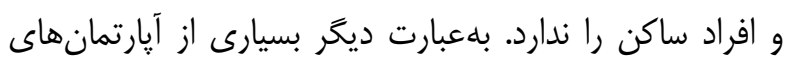

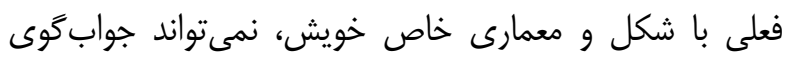
روابط انسانى خانوادههاى ساكن خويش باشنى خلند. (محسنى،

(1)

طرح بناهاى مسكونى به جمعيت، روش خاصى از زندگى و

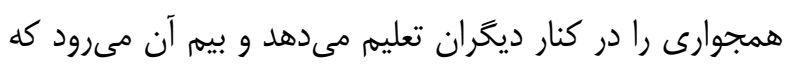

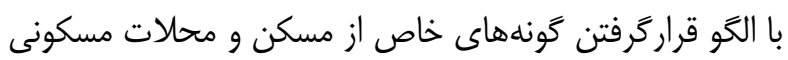

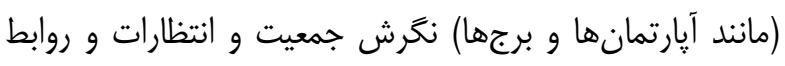
آنها با ديخر ساكنان دستخوش تحول كردد. (شيعه، سّسا:

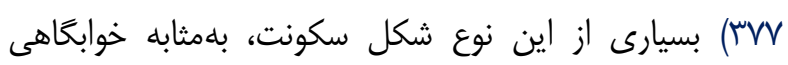

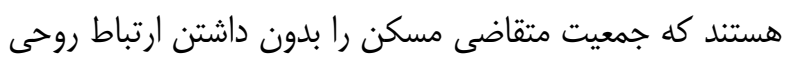

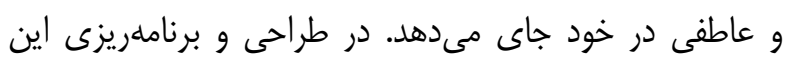
مجموعههاى مسكونى، كمتر توجهى به روابط همسايكى و و

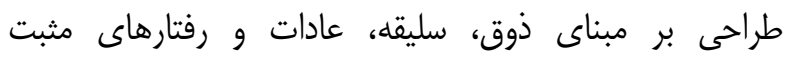

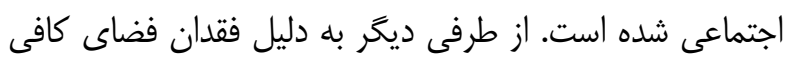
و تراكم بيش از حد و قيمت زمين، ساختمانها بدون وجود فضاى باز، نور كافى و ديدن افق و طبيعت بيرامونشان شكل مى گيرند. اين در حالى است كه معابر اطراف اين آيارتمانها

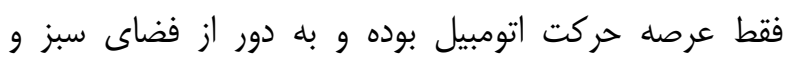
فضاهاى فرهنگى مانند مدرسه، كتابخانه و مسجد هستند. در

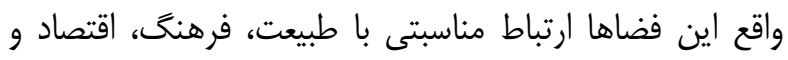

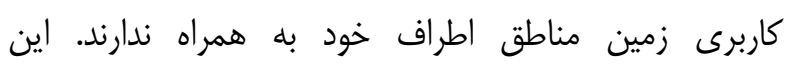

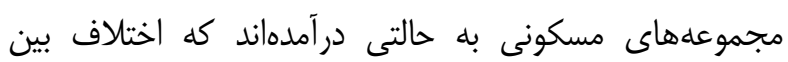


دو مسأله تأثير گذار است.؛ ) :

فريدمن در تحقيقى كه در سال 19Vץ در مجتمعهاى مسكونى

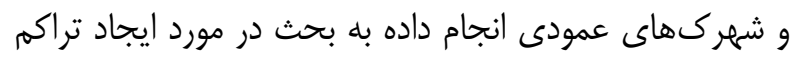

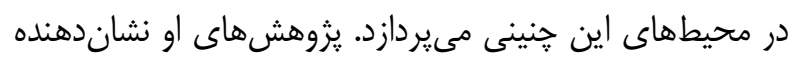

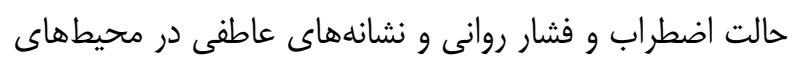

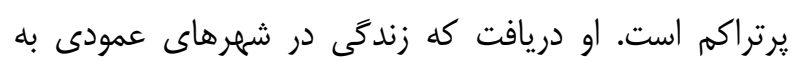
علت افزايش تراكم، ايجاد حس انزوا در كودكان و افزايش ميزان فشار عصبى، عدم تطابق جنسى، منفى خرايى، زودرنجى،

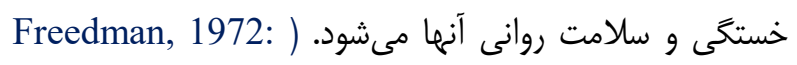

به دنبال اين نظريه تعدادى از يزوهشهاى تجربى به رابطه

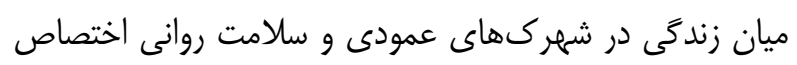

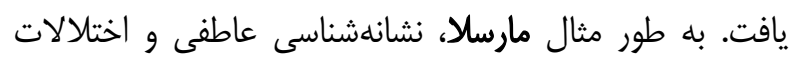

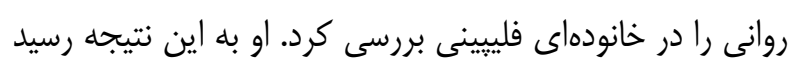

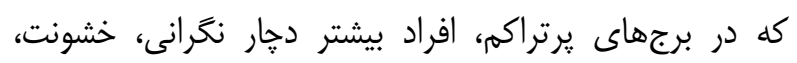

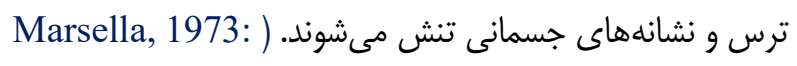
228) وى به اين مطلب كه در يزوهشهاى جامعهشناختى، همبستخى احساسهاى فرد نسبت به ديخران اندازهگيرى

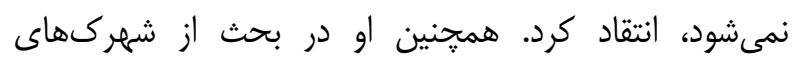
عمودى به مشكلات زناشويى، عدم نظارت بر كودكان، نبود

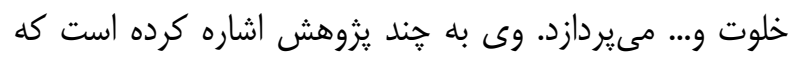

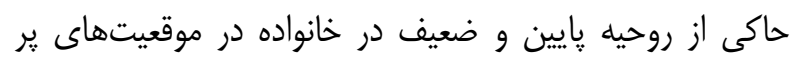

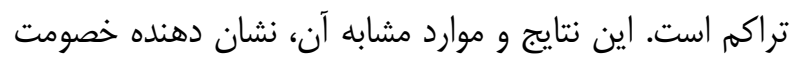

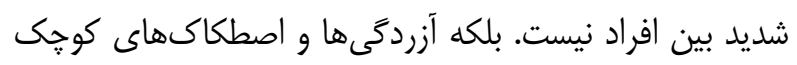
در موقعيتهاى ير تراكم را نشان مى دهد.

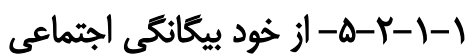

تحقيقات نشان داده است كه در محيطهاى آيارتمانى بلهرغم إنماعى

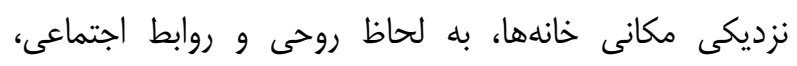
ساكنان آن روابط بسيار محدودى با هم دارند و در بسيارى از مانى

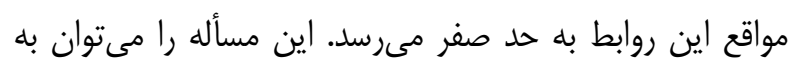
دليل تأثير ازدحام در اين محيطهاى مسكونى دانست. احساس ازدحام وقتى رخ مىدهد كه خلوت كسب شده كمتر از خلوت بdطوريكه افراد، عملكردهاى يكديگر را مطلوب نمىدانند و مانو

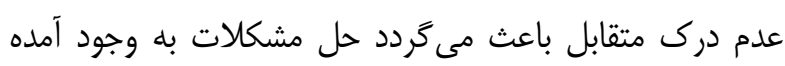

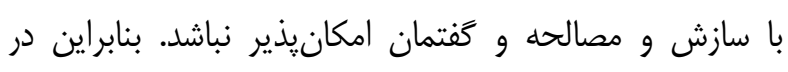

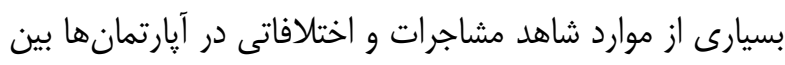
ساكنين هستيه كه از تنوع فرهنگى ساكنين نشأت مى گيرد.

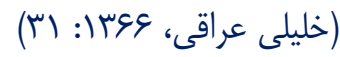

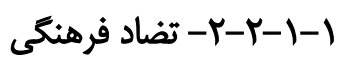
تنوع فرهنگى موجب بروز ناهنجارى به نام تضاد فرهنكى مى مهى

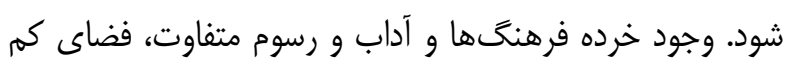
بناى آيارتمانها و نزديكى و در ارتباط بودن وندها و آنها با يكديكر، سبب بروز برخى اصطكاكهاى رفتارى و برخوردهاى فرهنكى إنى و به تبع آن ناهنجارىهاى رفتارى مى شود.

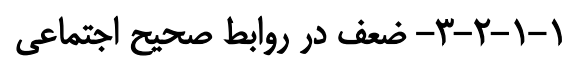
از سويى تنوع و تضاد فرهنگى و از سوى ديخر تراكم جمعيتى با مشكلات خاص خود و نداشتن روابط منسجم اجتماعى سبب

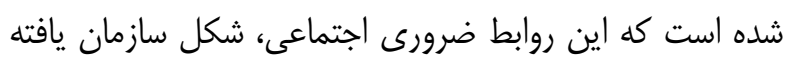

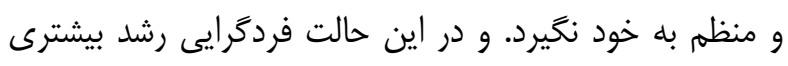

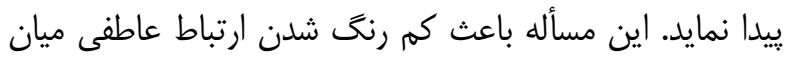

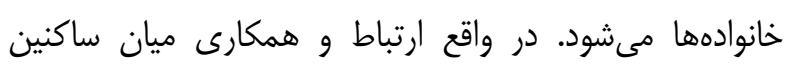
منازل مسكونى تكى واحدى در بسيارى از مواقع، علىرغه مهان بيشتر بودن فاصله جغرافيايى آنها از يكديخر، بيشتر است. I-I-I-Y-Y شهركهاى عمودى كه ساخت و ساز را در ارتفاع بلند ايجاب

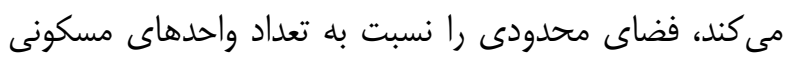
به خود اختصاص مى مهدد. از اين رو تراكم جمعيتى در ساختمان

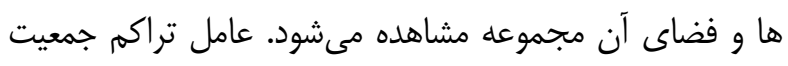

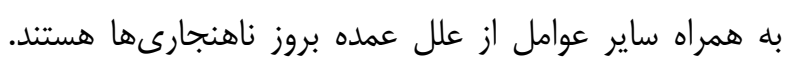
تحقيقات نشان مىدهد كه افراد در وضعيت متراكمتر بيشتر احساس ناراحتى كرده و قضاوتهايشان در مورد موقعيت، منفى مئى تر است. طبق يافتههاى تحقيق باكستر و دينوويج، الاندازه يك

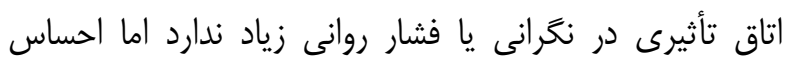

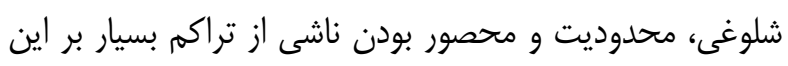


حرف زدن با وى كردند. اين مسأله نشان مىدهد زندگى در محيطهاى ير ازدحام تعامل اجتماعى را كاهش مى دهد.

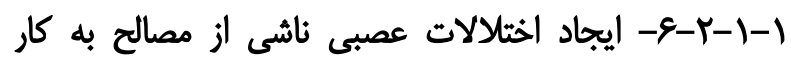
كرفته شده در مورد ساختمانهاى بلند مسكونى، علاوه بر توجه به مسائل فنى ييجيدهاى كه از اهم آنها مىتوان به مقاومت در برابر زمين مهان

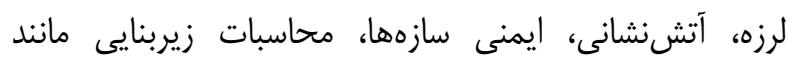

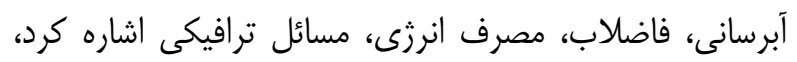

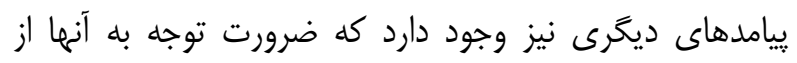
سوى طراحان و بهرهبرداران اجتنابنايذير است. از جمله مهمترين اين بيامدها تبعات زندگى خانوادهها در محيطهاى

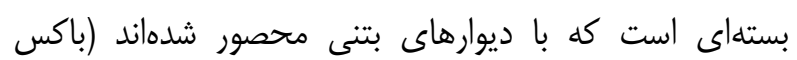

بتنى). اتحقيقات علمى، بيولوزى، طبى، روانكاوى كه از جانب فيزيك دانان به وضوح در مورد فولاد و بتن و... انجام شده، حاكى از ثبات تغييرات در حوزهاى الكتريكى طبيعى است كه روى ساكنين اين قبيل خانهها اثرات سوء باقى مى تذارد. طيف

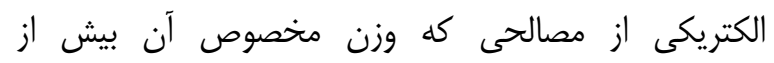

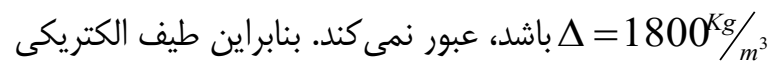
از بتن آرمه كه وزن مخصوص آن عبور نمى كند. اين نوع تأسيسات بر اساس طرز زندگى و و وضعيت انسانها شدت و ضعف ييدا مى كند، ولى به هر حال براى سلامتى مضر هستند. بر مبناى تحقيقات يزشكى تنش

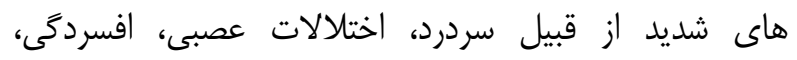

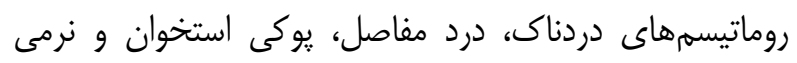

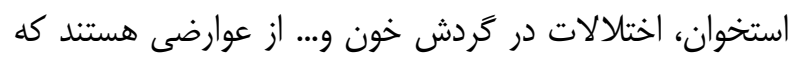

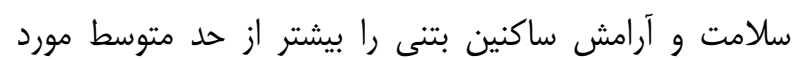

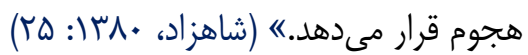

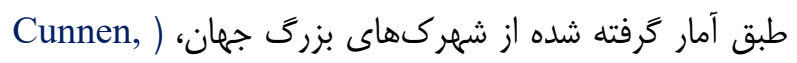
20 :1990) در آيارتمانهاى بلند مرتبه اين نوع اثرات روانى به لهنه

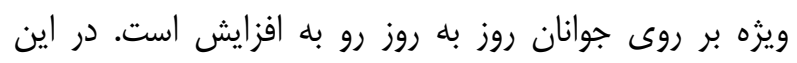
مجتمعهاى مسكونى به خصوص در راهروها و قسمتهاى
مطلوب - يعنى تعامل اجتماعى بيشتر از مقدار مطلوب آن باشد. (Altman, 1971: 67)

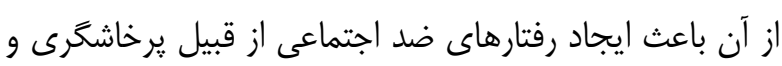
كوشه گيرى و در مواردى به صورت بروز بزهارى مى شود.

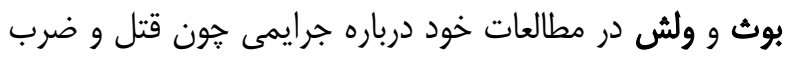
وجرح در مجتمعهاى مسكونى به مطالعه يرداخته و بـه اين

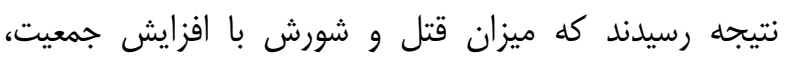

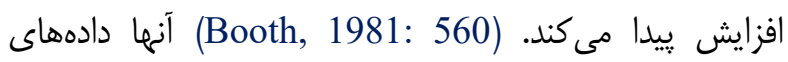
مربوط به هو كشور را بر حسب سه شاخص ازدحام، تعداد متوسط افراد در هر واحد مسكونى، تعداد واحدهاى مسكونى در

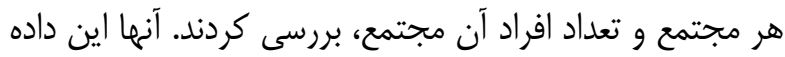
ها را با توجه به زنجيرء 》 ناكامى- تنشيرخاشكرى مجن تحليل كردند. آنها به اين نتيجه رسيدند كه تعامل بيشتر در خانههاى زئه

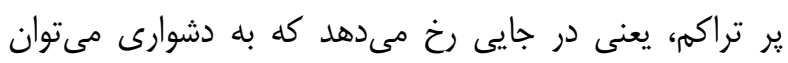

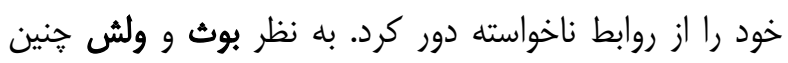
وضعيت سكونتى ممكن است باعث تنش و يأس روانى شود.

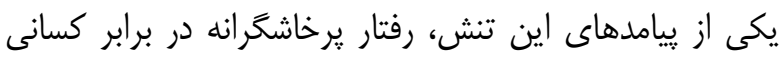

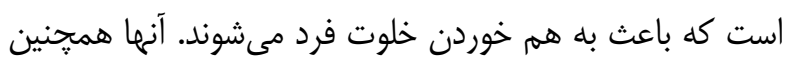

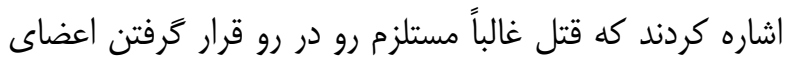
خانواده است كه در واقع بىواسطهترين منبع تجاوز به مرزها بلشمار مىرود. علاوه بر يرخاشكرى، يكى ديخر از مشكلات زندگى در برجها، ايجاد احساس گوشه گيرى است.

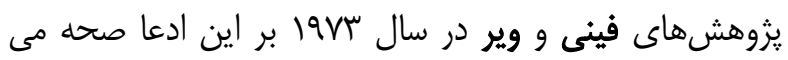
كذارد. مطابق اين بزوهشها (Feeney \& Weir, 1973: 38)

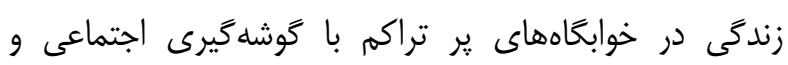

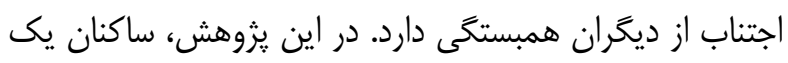

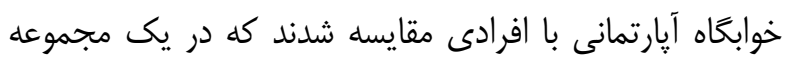

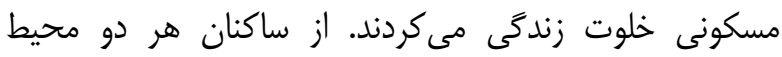
خواسته شد كه به اتاق انتظارى بروند كه همكار آزمايش كنتنه

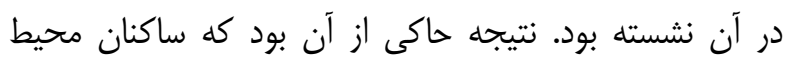
شلوغ نسبت به ساكنان محيط خلوت در فاصلهاى دورتر از فرد

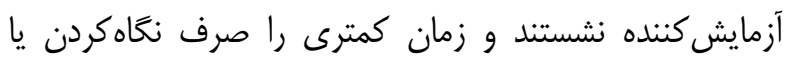


نتوانسته جذب نظام اقتصادى شهر شده و از خدمات شهرى

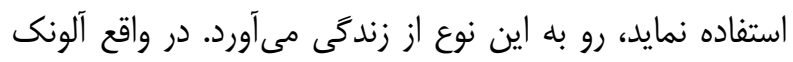

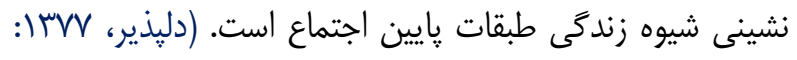
ها ) در بسيارى از شهرهاى بزرى، دولتها اقدام به اعمال سياستهاى ممانعتى در خصوص رشد جمعيت، كردهاند. حاصل اين سياستها، گسترش بىرويه شهرها در خارج از محدوده قانونى و به دنبال آن افزايش قيمت زمين و مسكن بوده است. تقسيم زمينهاى كشاورزى حاشيه شهرها و زمينهاى خارج محدوده، مهمترين شيوه دستيابى به زمين براى ايجاد

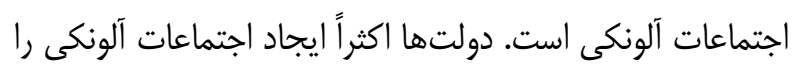
با اغماض مىنخرند. زيرا از سويى، صاحبخانه كردن بخشى از تهيدستان از تنشهاى متداول ناشى از فقدان مسكن كاسته و از سوى ديخر با كنترل هزينه خانوار و حذف اجارهبها، باز توليد

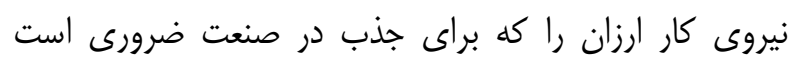
ممكن مىسازد. (ييران، Vوس ا: (D) "بررسى مناطق آلونكى نشان مىدهد كه نطفه اوليه بسيارى از

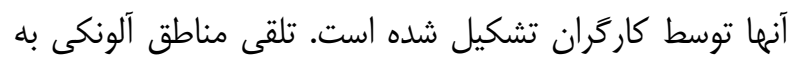
عنوان محل زندگى مهاجران روستايى درست نيست؛ جراكه درصدى از ساكنان محلههاى آلونكى، شهرنشينان با سابقهاى هستند كه قادر به تأمين سريناه در نقاط رسمى شهر نشدهاند.

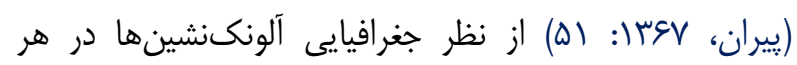

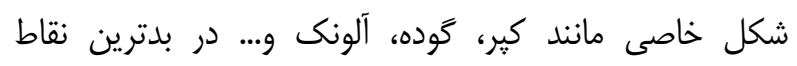
شهرى اسكان يافتهاند. در مورد يراكندگى جغرافي مانئيى آلونكها مى توان به زمينهاى بلامالك و اغلب غير قابل استفاده، زمين

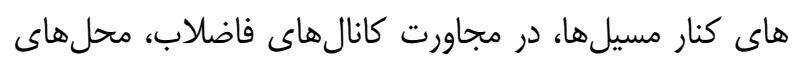

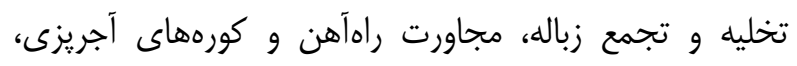

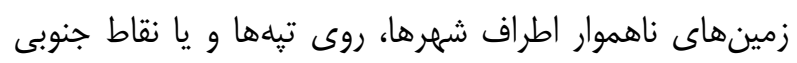

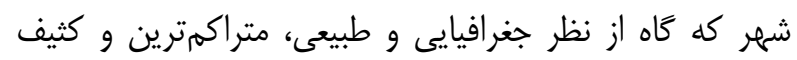

$$
\text { ترين نقاط شهرى هستند، اشاره كرد. }
$$

مناطق آلونكنشين داراى تراكم و درصد رشد بالايى نسبت بهرئ ساير مناطق شهر هستند. در اين مناطق، افراد زيادى متشكل از از

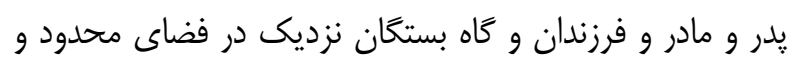
زير يك سقف زندگى مى كنند. اين تراكم در يك واحد مسكونى ونى ونى

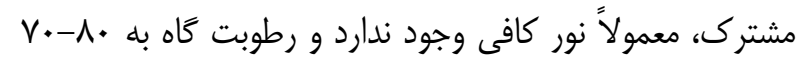
درصد مىرسد. در جنين شرايطى نوعى قارج بسيار ريز

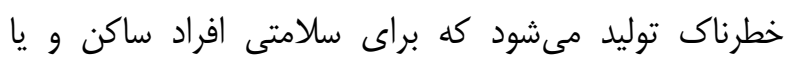

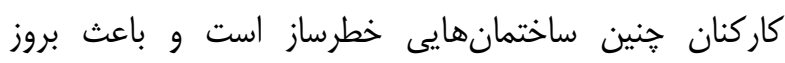

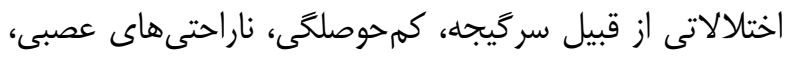
تنكى نفس، استفراغ، كمسويى جشمها مئشود. همجنين استفاده از ديوارهاى شيشهاى كه در برخى از برجها و آيارتمان

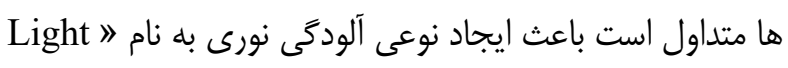
Pollution

|-I-Y-Y- كمبود فضاهاى فرهنكى، آموزشى و تفريحى و فقدان فضاى سبز فقدان و يا كمبود فضاهاى فرهنگى و آموزشى در مجتمعهاى سيز

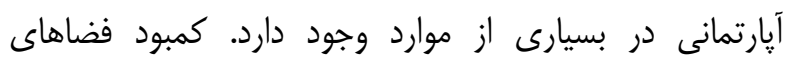
تفريحى باعث به خطر افتادن سلامت بزرگسالان و آزادى عمل مورد

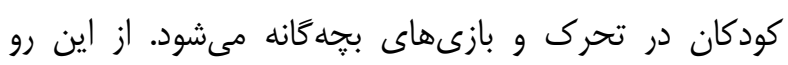
سلامت روان و جسم آنان در معرض خطر قرار مى گيرد.

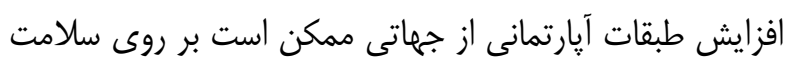

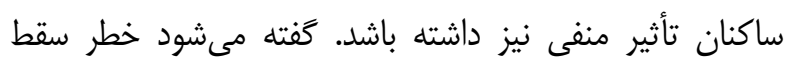
جنين زنان باردارى كه در طبقات ينجم به بالا سكونت دارند

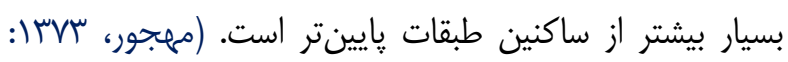

طراحى فضاى سبز نيز يكى از بخشهاى مهرم در محلهاى

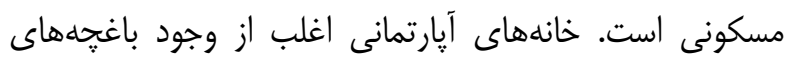

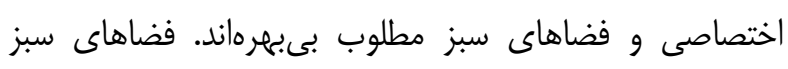
باعث رهايى افراد از مشكلات زندگى شهرى و بهدست آوردن آرامش حتى براى مدت كوتاه يارى مى شود. زيبايى خاصى كه إنه

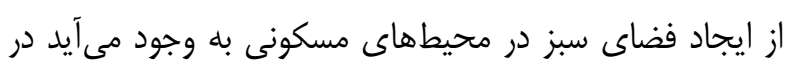
بهبود روان ساكنان آن محيط مسكونى موثر است.

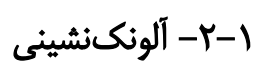

ו-ץ-ו- طرح بحث. آلونك نشينى يا "امسكن خود ساز " يا

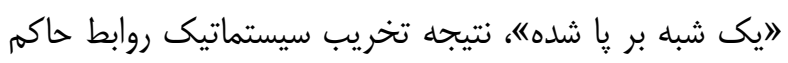
بر اقتصاد و رواج الخوى مصرف گرايى و گسترش شهرها است. در واقع كسى كه در شهر سكونت دارد ولى به علل گوناگون 
دارند. در بعضى از موارد نيز قاجاق مواد مخدر در بين آنان

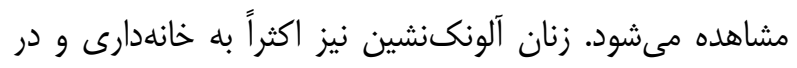
برخى موارد به دورمخردى، كفبينى، لباسشويى و كار در منازل

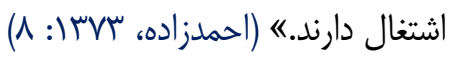
عوامل متعددى منجر به بروز آلونكنشينى مىشود. عمدهترين آنها دو عامل اساسى "حريزاننده" و "جذب كننده" است. افراد

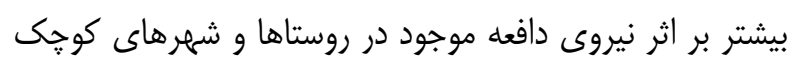

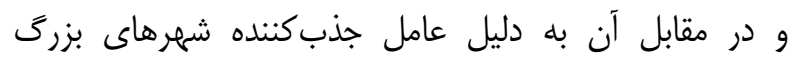
مهاجرت مى كنند. زمانى كه عامل "يسران" شهرى (هزينه

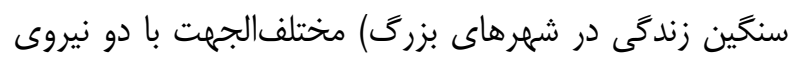
ييشين، سدى بزرى در مقابل مهاجرين در متن اصلى شهر قرار

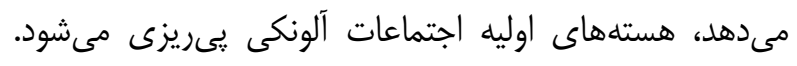

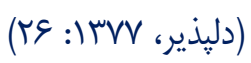

I-Y-Y- آلونكنشينى: مسائل فرهنكى و رفتارى

تقريباً تمامى مشكلات فرهنكى آيارتمان نشينى در مورد آلونكى

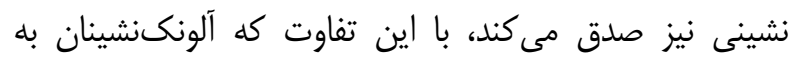

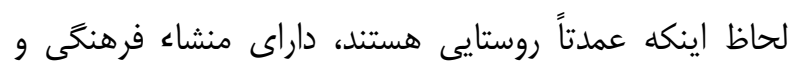

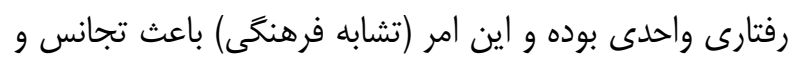

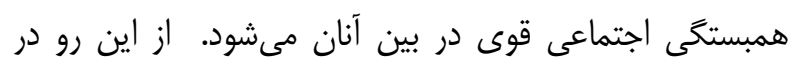

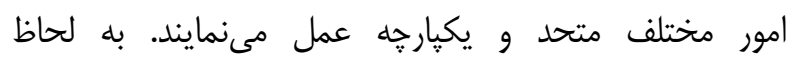
خصوصيات خاص آلونكنشينى، مسائل رفتارى ديخرى را نيز مىتوان در نظر گرفت.

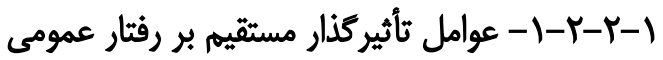
ו-r-r-1-1- واكنش سريع به نآرامىهاى سياسى

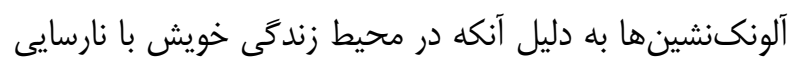

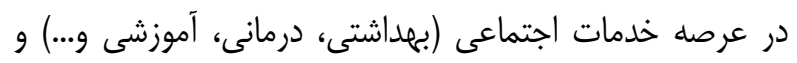
تراكم زياد جمعيت در واحدهاى مسكونى تنگ و نابسامان خويش روبرو هستند، همواره خواهان بهبود در اين امور هستند. آلونكنشينها همواره طالب دولتى هستند كه به وضع هوبن هون آنان رسيدگى نموده و مشكلات را مرتفع نمايد. لذا بسيار زود به همان سوى كسانى كه به آنان وعدههاى مختلف مى مدهند، كشيده شده و در ناآرامى هاى سياسى شر كت مى كنند.
كاه منجر به رؤيت روابط خاص افراد از قبيل روابط جنسى

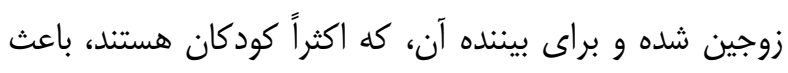
ايجاد انحر اف فكرى مىشود. "طبق يك نمونه بررسى شده در برد

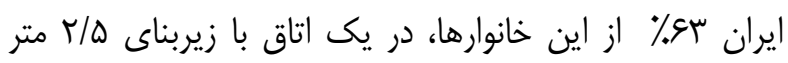
زندگى مى كنند. در حالى كه طبق استاندارد ميانخين زيربناى

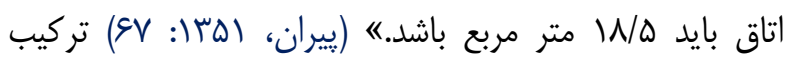
جمعيتى اجتماعات آلونك نشينى اكثراً از طبقه جوان است.

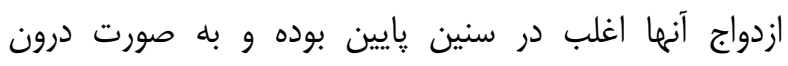
همسرى مىباشد. تحقيقات انجام يافته نشان مىدهد كه به به تقريباً يك سوم آلونكنشينان كسانى هستند كه از جمعيت خانوارهاى موجود متولد شدهاند. مناطق آلونك نشينى عمدتاً فاقد آب آشاميدنىاند. ساكنين اين

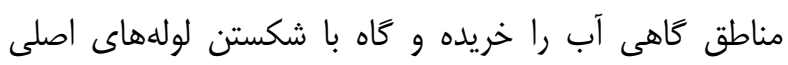

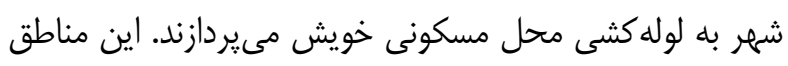

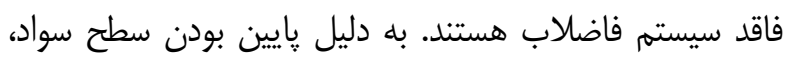
امكان استفاده از روشهاى صحيح بهداشتى وجود ندارد. از

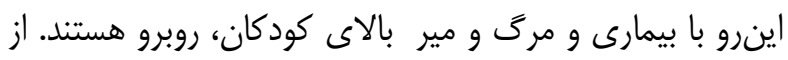
سوى ديكر، كودكان به منظور كسب درآمد از رفتن به مدرسه مانه

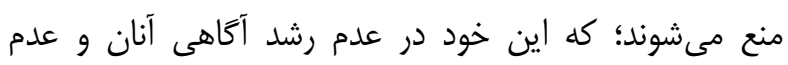
امكان ايجاد فضايى براى شناساندن هنجارهاى جامعه و قوانين

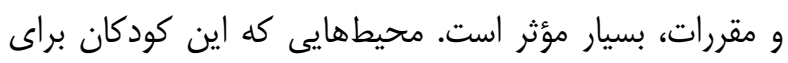
كار به آنجا مىروند اغلب محلهايى است كه فساد در آنجا زياد

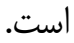
آآلونكنشينها عمدتاً در منافع مشترك از جمله در امور

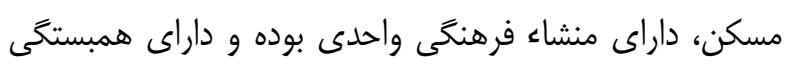

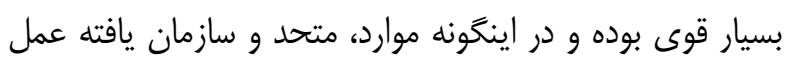

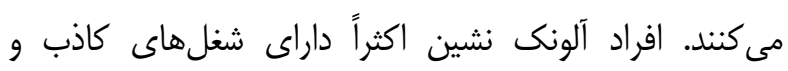

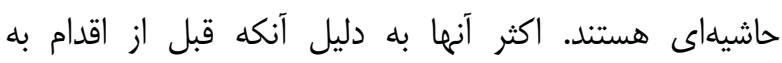
مهاجرت، كشاورز بودهاند و يا در اين بخش مشغول فعاليت بوده

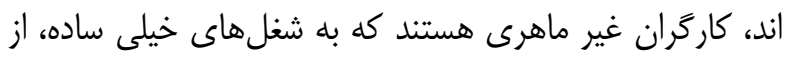

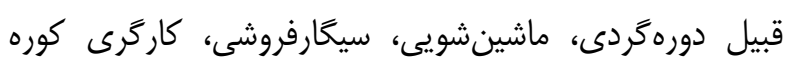
يزخانه، دستفروشى، رانندگى، بادكنى فروشى و.... اشتغال سيكال 


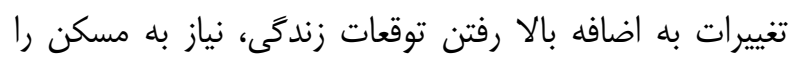

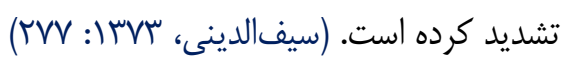
"ادولتها براى حل اين معضلات اقداماتى را انجام دادهاند. يكى از اين اقدامات را مىتوان برنامهريزى براى احداث واحد هاى مسكونى با مساحت كم براى خانوادههاى جوان و كم

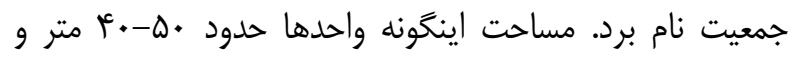

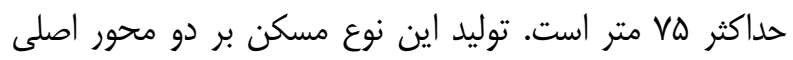

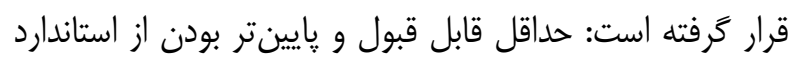

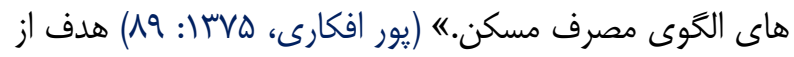
ايجاد اين نوع مسكن، تأمين سريناه براى زوجهاى جوان، اقشار

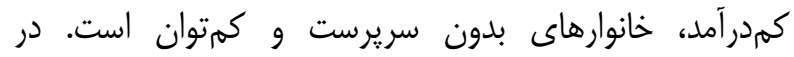
بسيارى از موارد اين نوع مسكن تحت عنوان بلوى ناميده مى بـ

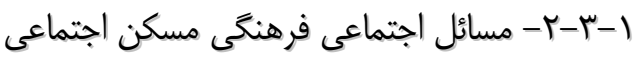
تجربه كشورهاى مختلف با نظامهاى اقتصادى و اجتماعى اجى متفاوت، حاكى از آن است كه هر كشور به تناسب ساختار اقتصادى و اجتماعى خود، و با وجه اجتماعى مسكن برخورد مى كنند. دخالت دولتها در حل مشكل مسكن وقتى اهميت مى اجى يابد كه بدانيم مشكلات دستيابى به مسكن، خود اثرات و عواقب اجتماعى بى شمارى دارد كه در روند شكليَيرى خانواده

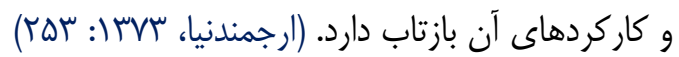
شايد مهمترين مسأله رفتارى يك محيط مسكونى، ايجاد زمينه مناسب براى انطباق كودكان با اجتماع ييرامونش باشد. از اينرو

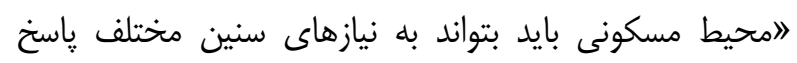

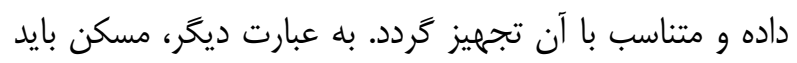

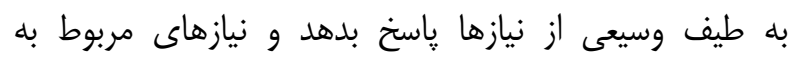

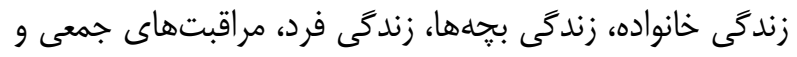
نيازهاى مربوط به محيط يِيرامون مسكن را يوشش دهد.

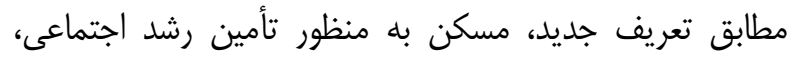

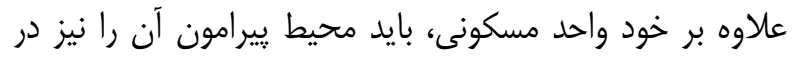

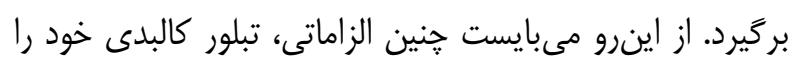

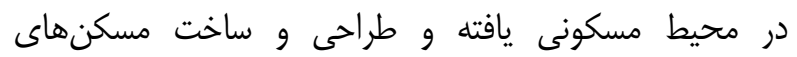

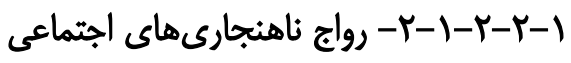

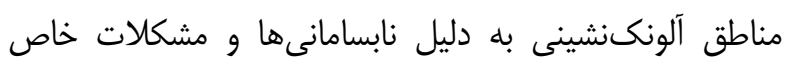
خويش، زمينه مناسبى را جهت نمو و گسترش آسيبهاى اجتماعى و رواج بزهكارى فراهم مىنمايند. قتل، اعتياد به مواد مخدر و يخش و فروش اين مواد و روسييكرى از نمونه مسائل اجتماعى است كه در اين مناطق زمينه ظهور و بروز فراوانى

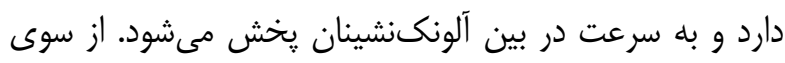

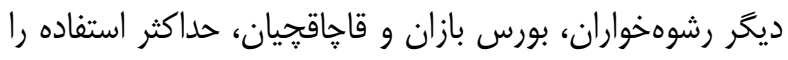
از مردم اين محلها به عمل مى آورند.

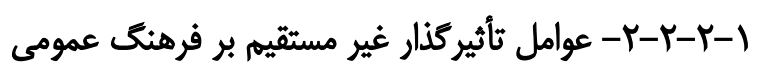
از يك سو عدم تطبيق ساخت مناطق آلونكنشينى با اصول صحيح شهرسازى، مغايرتى را در شكل و بافت شهرى ايجاد كرده و از سوى ديخر، ابه دليل فقدان تأسيسات و امكانات رفاهى و خدماتى لازم، از امكانات بخشهاى درئ مجاور كه خود

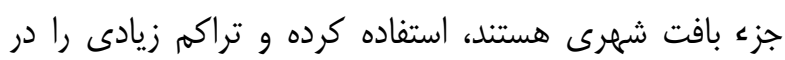
اين قسمتها به وجود مىآورند. از اينرو امكان استفاده ساكنين محلات شهرى مجاور خويش را محدود مى منند. ايجاد

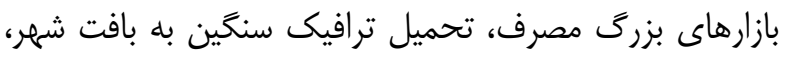
تراكم و ازدحام بالاى جمعيت در سطح شهر، رواج دستفروشى و بحري ايجاد نامنى براى ساكنين، از تأثيرات ديخر وجود اين اجتماعات

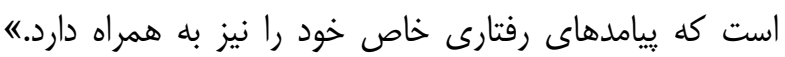

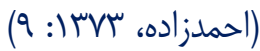

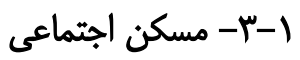
ו-ץ-|- طرح بحث. افزايش سريع جمعيت از يك طرف و و

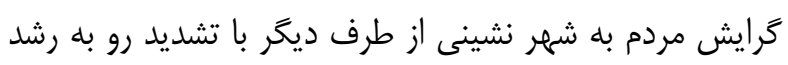
تقاضاى تهييه مسكن، مشكلات زيادى را در زمينه توسعه

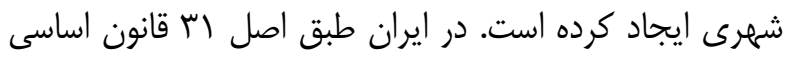
داشتن مسكن متناسب با نياز خانواده، حق هر فرد ايرانى است. اين مسأله در قوانين بسيارى از كشورهاى ديخر نيز مشاهده مىشود. در كنار اين مسأله بايد به تغيير در ابعاد خانوار و

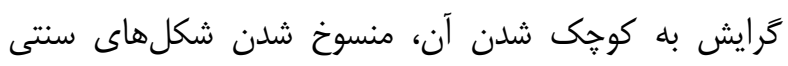
زندكى، گسستن افراد مزدوج از والدين خود از نقطه نظر مسكن كه مىتوان از عوامل بحران مسكن نام برد، توجه كرد. اين 
در محيط شهرى رنخ را در همه جا مىتوان ديد، در بدنه و نماى ساختمانها، يوشش بام، كفسازىها، مبلمان شهرى، فضاى سبز، خودروها و.... در جوامعى كه رنخَهاى تيره و كدر

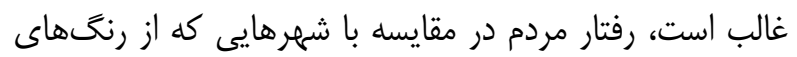

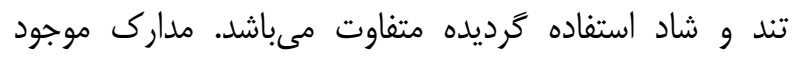

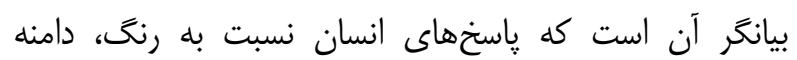
فيزيولوزيكى وسيعى را به خود اختصاص مىدهد. بهعنوان

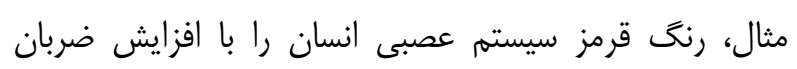
قلب، حركات سيستم تنفسى و يلك زدن جشم، فشار خون و

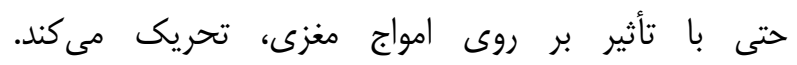
(Healing.about.com, 2020) رنت آرامش بخشى است كه به كاهش فشار خون و تنظيم سيستهم تنفس جشم كمك مى كند. در مكانهاى متفاوت، از

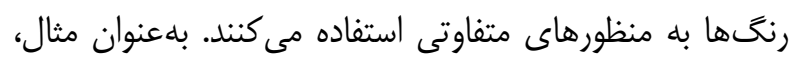
صورتى رنغى است كه نتايج قابل توجهى را به بار منى آورد.

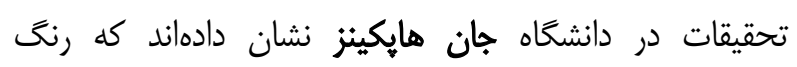
صورتى در افراد باعث توقف اشتها شده و نياز به غذا خوردن در دران دهرين Oselink.com, ) حالتهاى فشار و استرس را كاهش مى مهند

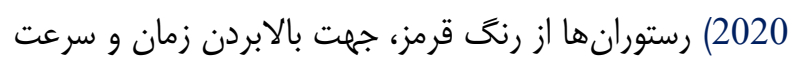
غذا خوردن و خروج سريع مشتريان از رستوران استفاده مى رسى

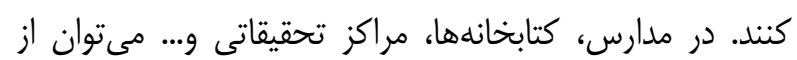
رنخهاى گرم و ملايم مانند رنگ هلويى جهت بالابردن

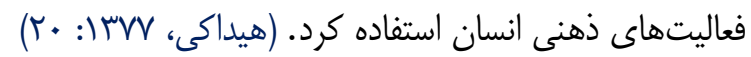

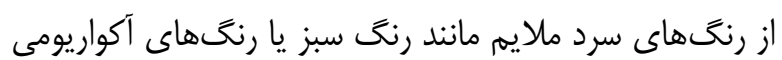

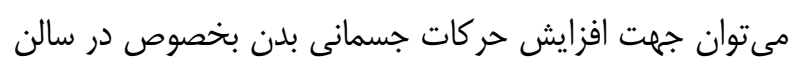

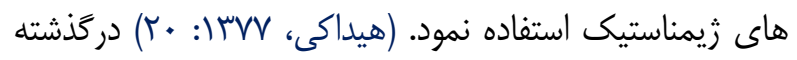
به مدت طولانى از رنغهاى ملايم و آرام در كارخانجات، مدارس ساختمانهاى ادارى و دولتى استفاده مى كردهاند. در حالى كه مطالعات نشان داده است كه استفاده از جنين رنى فئ هايى براى مكانهايى كه افراد مدت طولانى را در آن سيرى

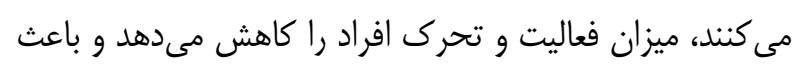
افسردگى آنها مى شود. (Healing.about.com, 2020) تجربيه
اجتماعى، آن را مورد توجه عميق خويش قراردهد.) (جيبى و

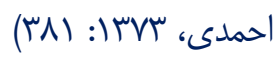

در جستجوى تأمين اين نيازها در مسكنهاى حداقل، خانواده يا بخش بزرگى از آن (مادر و فرزندان) به محيط خارج از مسكن ائن يناه مىبرند. به عبارت ديكر لايكى از تبعات كوجکكسازى مسكن، كشاندن بخش اعظم فعاليتهاى كذران اوقات فراغت و يا حتى اشتغال به خارج از منزل است. بدين ترتيب، تأمين

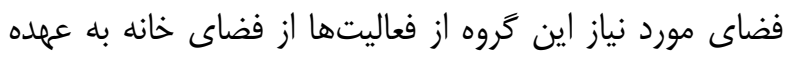
فضاى عمومى شهر كذاشته مىشود. اين امر كذشته از آن كه تأثير قابل توجهى در طراحى شهر و فضاى عمومى شهر دارد، اگر مورد غفلت قرار گيرد، مىتواند به كاهش وابستخى اعضاء

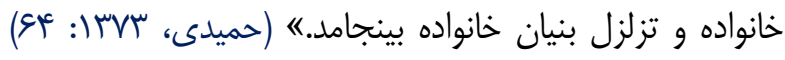
بنابراين تجهيز و تأمين بخشهاى مكمل و وييرامون مسكن مانند مدرسه، يارك، زمين ورزش و... كه به تنهايیى از عهده مردم خارج است، وظيفه دولتها را در ايجاد جنين تجهيزاتى مانى

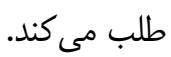
برخى صاحبنظران به اثرات تخريبى و فرهنكى اين نوع مسكن در زندگى فردى، خصوصى و جمعى افراد نظير كوجى شدن

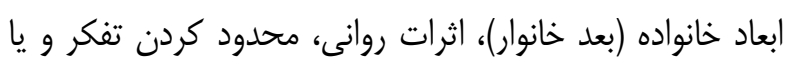
نداشتن مجال تفكر سياسى، توسعه شايعات و... اشاره كردهاند.

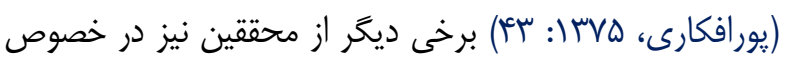
اين نوع مسكن به يك مشكل عمده اجتماعى و رفتارى، اشاره

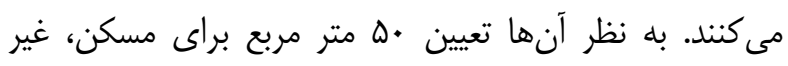
استاندارد و مغاير با خلقوخو و عادات و رسوم مىباشد. (دادور،

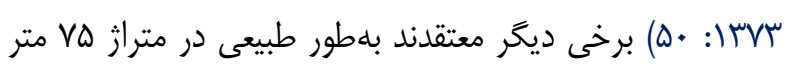

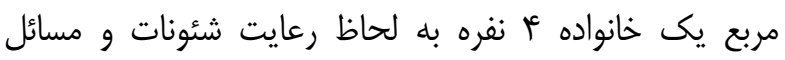
مرتبط با رفتار اجتماعى، به سختى مىتوانند زندگى كنند. (ديبا،

(1. : I)A r- تأثير محيط بر رفتار: فاكتورهاى طراحى r رنغى يكى از جنبههاى مهم زندگى شهر است حقيقت اين است

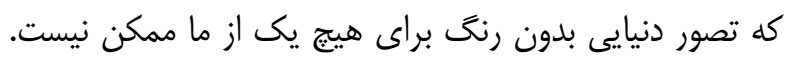


رنتى شهر بايد در جهار سطح شهر يا منطقه، خيابان يا ميدان،

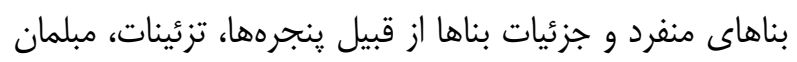

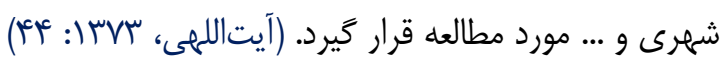

$$
\text { r-r- زيبايیى طراحى }
$$

امروزه توجه به اين نكته كه فضاهاى شهرى صرفاً محل تردد شهروندان از محل سكونت به محل كار و يا تنوع نبوده، بلكه

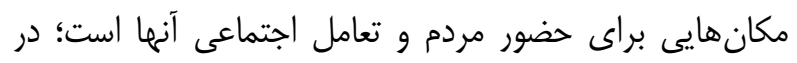
طراحى شهرى حائز اهميت است. بنابراين طراحى فضاهاى

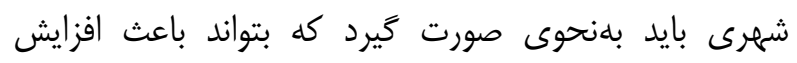

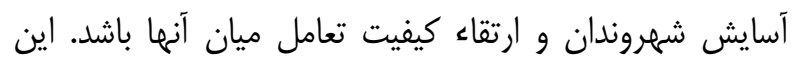
مهرم مىتواند باعث ايجاد رفتارهاى مثبت در شهروندان گرددد. به اين طريق مىتوان از بروز بسيارى از ناهنجارىها كه كَاه در

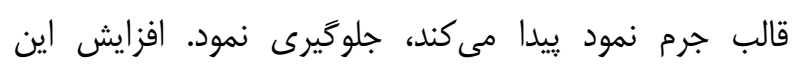
تعاملات اجتماعى با ايجاد فضاهاى قابل دفاع، تأثير مستقيم و و ندود

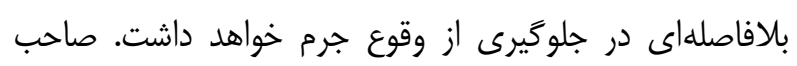
نظران معتقدند در هر يك از فضاهاى شهرى جه در سطح كلان (شهر يا منطقه) و جه در سطح خرد (نقاط مسكونى)،

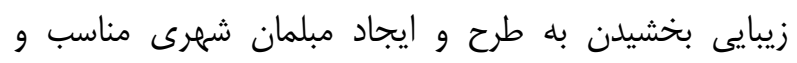

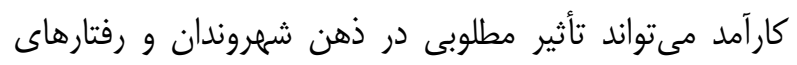

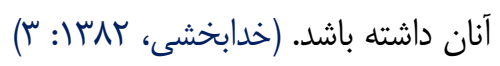
فضاهاى شهرى بايد به كَونهاى باشند كه شهروندان به راحتى

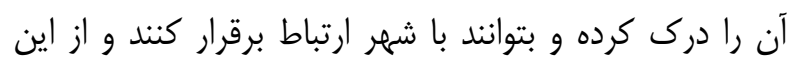
طريق ريشههاى تاريخى و فرهنگى خود را دريابند. براى

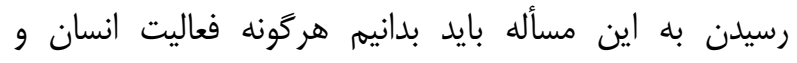

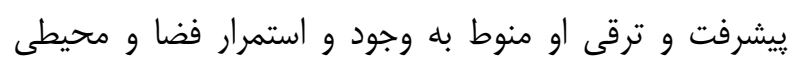
مناسب جهت زندكى و زيستن است. با اين وجود در بسيارى از شهرها، سياستها و طرحهاى توسعه شهر با مطالعات زيست محيطى و ايجاد الخوى مناسب جهت مهيا نمودن شرايط مطلوب انسانى و حفظ آرامش روانى شهروندان، هماهنى نيست. در بسيارى از طراحىهاى شهرى، طراحى فيزيكى بر

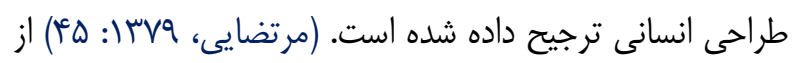
اينرو عدم توجه به جنبههاى انسانى در طراحى و معمارى فضاهاى شهرى (اعم از فضاهاى سبز، ساختمانها، خيابانها،
نشان داده است كه استفاده از رنخهاى زنده، سبب بالا رفتن روحيه كاركران، بيماران و كاهش يريشانى خيال آنها مىشود.

(Van Der Voordt, 1988: 260) ادانشمندان در مورد رنغ ها و شدت نور تحقيق كرده و دريافته اند كه رنخَها در افراد، احساسات مختلفى را ايجاد مى كنند. آنها از اين خاصيت استفاده كرده و بحث رنحَ درمانى را مطرح

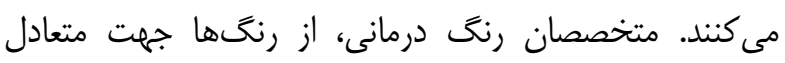

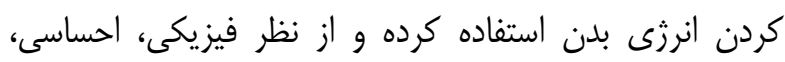
روحى و روانى فرد را متعادل مىسازند. نورهاى رنكى، منشورها، يارجههاى رنكى برخى از تسهيلاتى هستند كه در رنغ درمانى

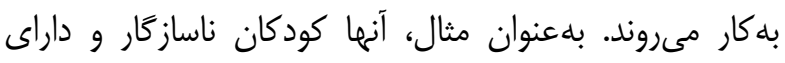
حالت تهاجمى را در كلاسهايى به رنخ آبى قرار داده و مشاهده كردند كه حالات تهاجمى آنها به شدت كاهش راته يافت.

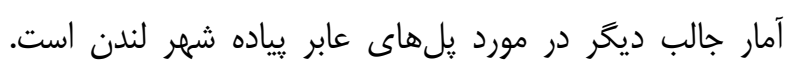

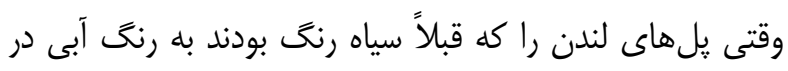

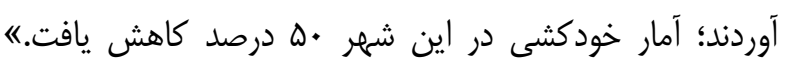

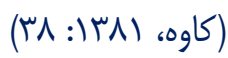
مديريت رنغ در طراحى ساختمان و بهخصوص در شهرسازى (آنى

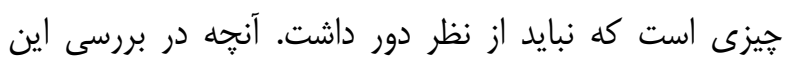

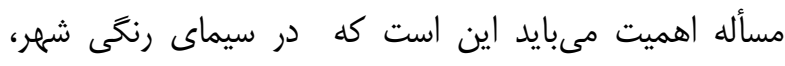

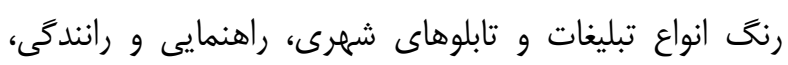

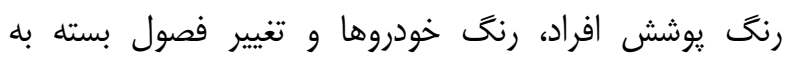

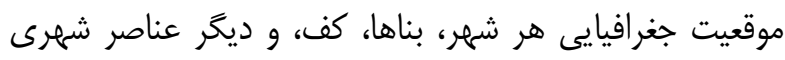

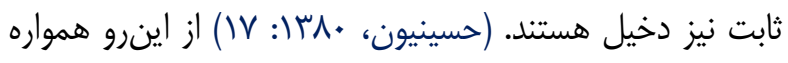

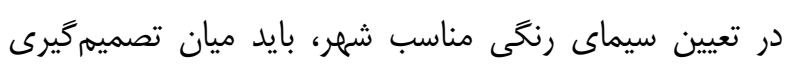
اركانهاى مسوول در مورد رنخ عناصر، هماهنخى بلهعمل آيد. در طراحى شهرى، طراح بايد عناصر اصلى شهر، نواحى، مهن، مسيرها، كره و لبهها را شناسايى كند و بر مبناى بررسى دقيق بايق رنخَهاى محلى در محيط، طرح جامع رنكى شهر را تهيه نمايد.

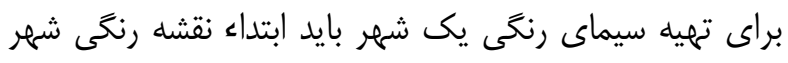

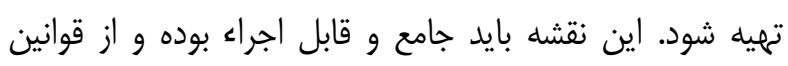

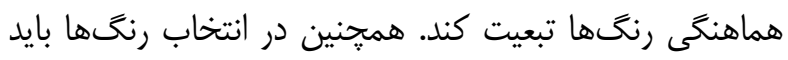

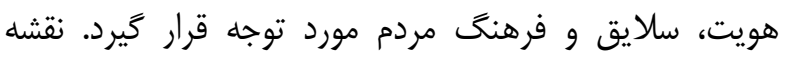


از فضاهاى سبز عمومى علاوه بر كاركرد فوق مىتوان در كاهش آلودَى صوتى نيز بهره جست. بهطور كلى، صداهايى

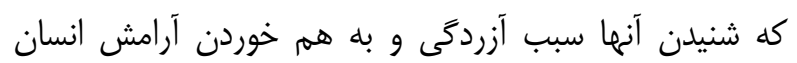
شود، آلودخى صوتى ناميده مى شود. درختان مختلف به حسب آنس اندازه برى، تراكم شاخ برى و ارتفاعشان بر روى آلودگى صوتى مؤثر هستند و بلعنوان يك مانع ارزان و كارآمد در راه كاهش آلودگى صوتى موتى هواند مورد استفاده قرار گيرند. اصولاً هرقدر ارتفاع درخت و تراكم تودهاى بيشتر باشد، اثر كاهش مونى

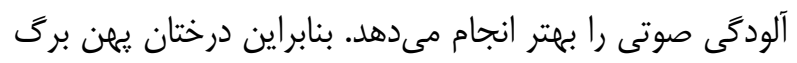
در مقايسه با درختان سوزنى به دليل سطح وسيع شاخ و برى تأثيرات بيشتر و بهترى دارند. شاخ و برى درختان به به دليل ديل ديل قابليت انعطاف و نرمش و صاف بودن، صدا را جذب مى كنند. تنه اين درختان و شاخههاى سنخين نيز باعث انحراف صدا

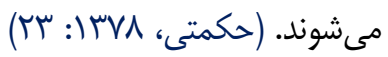
از مجموع آنجه گذشت بهدرستى استنتاج مىشود كه محيط

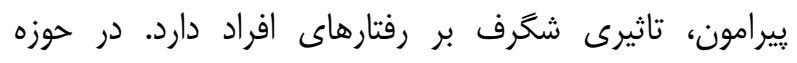

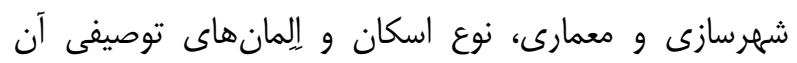
همجون نحوه استفاده از رنغَها مىتواند در سبك زندگى و شيوه تعاملات اجتماعى افراد در جامعه تاثيركذار باشد. علاوه بر نوع و شكل مسكن، عوامل و شيوههاى طراحى نيز در رفتار

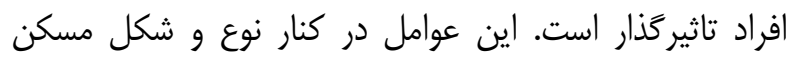
مىتواند رفتار انسان را شكل دهد. در پايان اين نوشتار، جهت

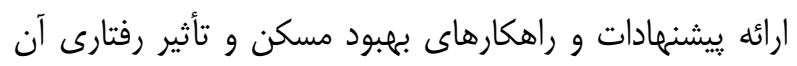
مىتوان موارد ذيل را مورد نظر قرار داد: 1- ترويج ضوابط شهرسازى و استفاده از تئورىها و ضوابط علمى شهرسازى و تكيه كردن آن بر الكَوهاى رفتارى؛

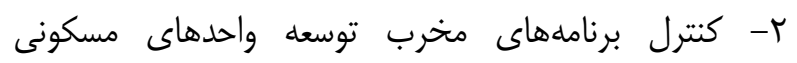
نامتجانس كه عموماً از طريق بسازبفروش عرضه مى شودا. اين برنامه تأثيرات منفى فراوانى در رفتارهاى افراد ايفا مىنمايد؛
يارك ها، معابر، ميدانها، مغاز مها و ساير فضاهاى شهرى) باعث

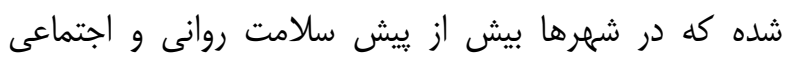
ساكنين در معرض آسيب باشد. بهعنوان نمونه "انيومن و كولمن مطرح مى كنند كه بلوكهاى مسكونى مرتفع، مكانهاى "نامناسبى براى زندگى هستند. همجنين در برخى موارد آنها

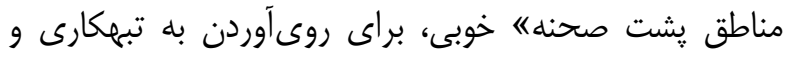

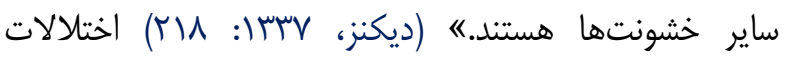

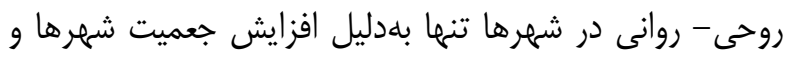

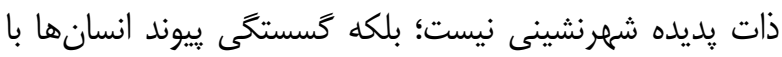
طبيعت رامىتوان از عوامل مهم در بروز اين اختلالات دانست. جهت ايجاد اين ييوند، طراحان شهرى مىتوانند در كنار كسترش فيزيكى، به جنبهاى انسانى طراحى از طريق ايجاد فضاهاى سبز در شهرها بيردازند. افضاى سبز شهرى، به مجموعه فضاهاى آزادو سبز موجود در داخل محيطهاى شهرى كه داراى اهداف مشخص و عملكرد

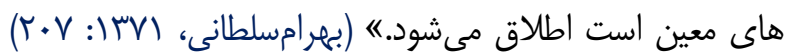
اين فضاها مىتوانند شهروندان را از مشكلات زندكى شهرى دور كرده و در بهدست آوردن آرامش حتى براى زمانى كوتاه،

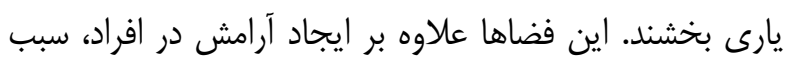

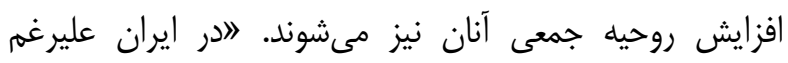

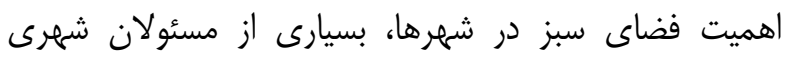

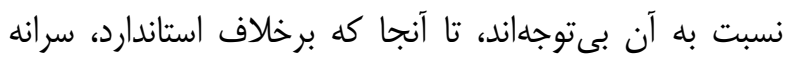
هr متر مربع فضاى سبز، اين ميزان در برخى از شهرها به ب تا

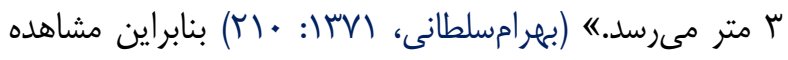
مىشود كه با يك تغيير و برنامهريزى ساده مىتوان محيط شهر

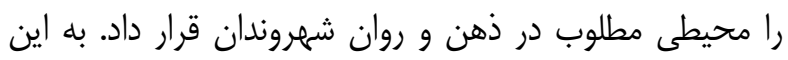

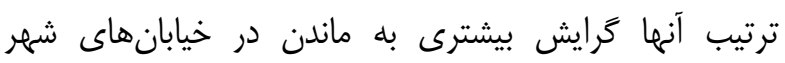
خواهند داشت. اين امر كه باعث افزايش تعاملات اجتماعى و افزايش تعلق خاطر شهروندان به محيط شهرى خود مىشود. احساس تعلق خاطر افر اد به محيطشان مىتواند از عوامل بسيار مؤثر در ييشگيرى از وقوع جرم باشد. 
9- ايجاد فضاهاى مكمل به دليل محدوديت ابعاد و فضاى مسكن اجتماعى.

ملاحظات اخلاقى: موارد مربوط به اخلاق در يزوهش و نيز امانتدارى در استناد به متون و منابع رعايت كرديد.

تعارض منافع: در تدوين اين مقاله، هيج نوع تعارض منافعى وجود نداشته است.

سهم نويسندكان: تمامى امور اين تحقيق توسط نويسنده طبق

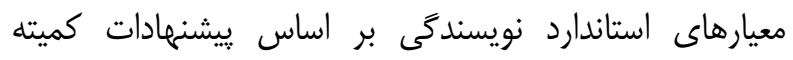
بين المللى ناشران مجلات حقوقى صورت گرفته است. تشكر و قدردانى: در به سامان رساندن اين يزوهش از دوست دوستان يزوهشكَ خود در رشته معمارى، سياسگزارم.

تامين اعتبار يزوهش: اين يزوهش فاقد تامين كننده مالى بوده

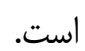

r- تأمين فضاهاى مورد نياز محلهاى به نسبت تعداد و شعاع

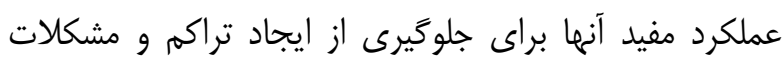

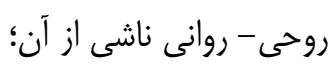

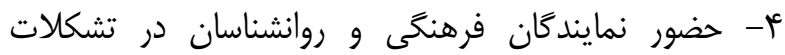
مسكن و شهرسازى و شهردارىها و همكارى متخصصين معمارى با متخصصين علوم رفتارى و اجتماعى؛ ه- توجه به نيازهاى روحى و معنوى انسان در معمارى و مولمين

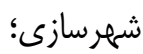
צ- ايجاد واحدهاى مسكونى جديد جهت پاى كردن إن مناطق

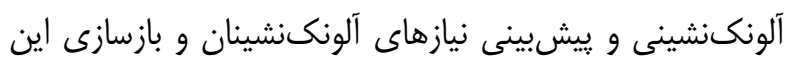

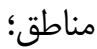
V- جلب نظر مالكين خانهها و مستأجرين در اين مناطق در

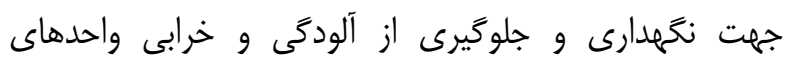
مسكونى (با توجه به آموزههاى مكتب شيكاكو)؛ ^- شناساندن الخوهاى رفتارى مناسب با بآيارتماننشينى و وهائ تقويت روابط همسايكى؛ و 
منابع و مآخذ

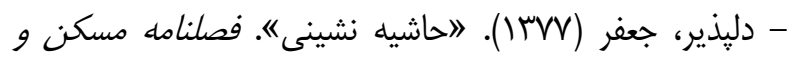

الف. منابع فارسى

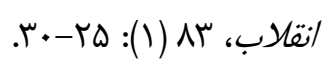

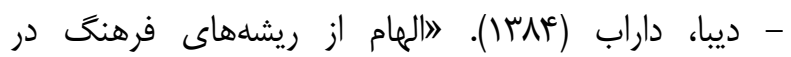

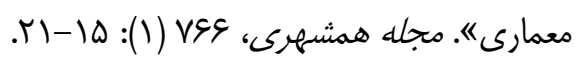

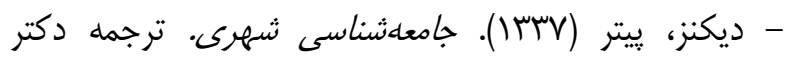

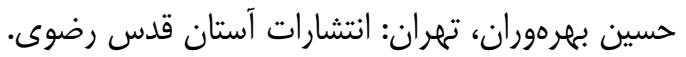

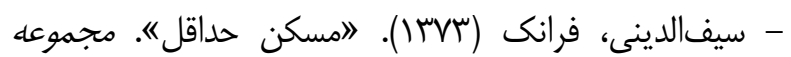

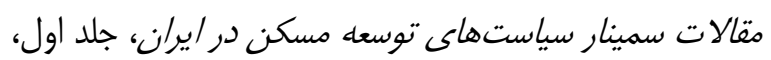

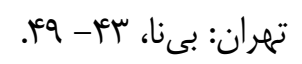

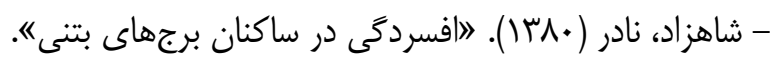

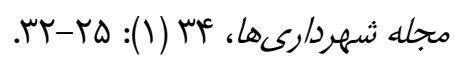

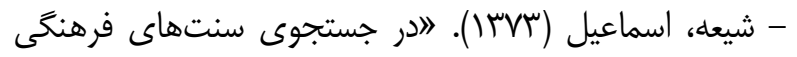

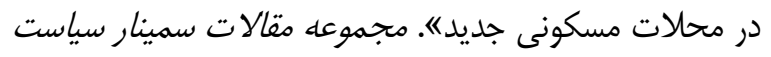

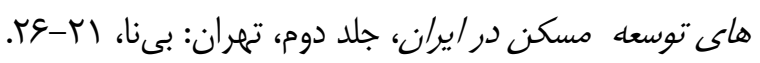

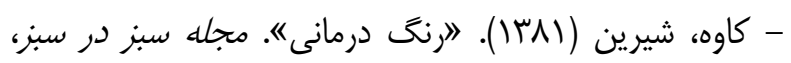

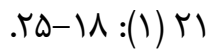

- محسنى، مرتضى (IrVN). ياسخ هايى به خشونت. تهران:

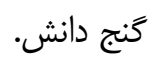

- مرتضايى، فرهاد (IYYY). (اطراحى مبلمان براى خيابان".

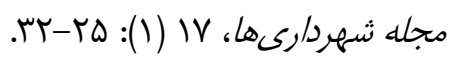

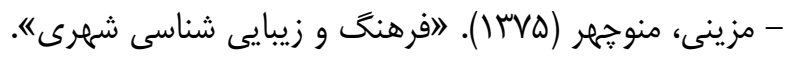
فصلامه فرهنگ عمومى، 19 (1):

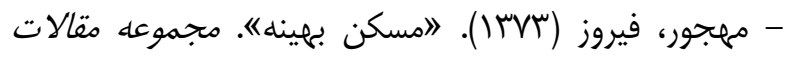
سمينار سياستهاى توسعه مسكن در /يران، جلد دوم، تهران:

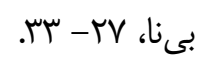

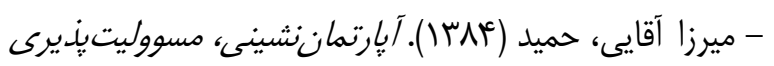
و آرامش در زندكى. تهران: انتشار فكر نو.

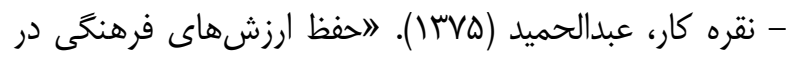
معمارى و شهرسازى". فصلنامه فرهنت عمومى، 19 (1) (1):

.rT- Th

- هيداكى، شى جىوا (ITVV). همنشينى رنخها. ترجمه فريال دهدشتى، شاهرخ و ناصر يور ييران، تهران: نشر كارنخى.

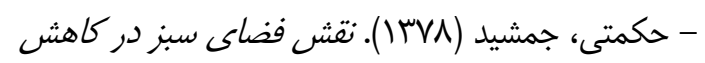
آلودكى صوتى در شهرها. تهران: نشر ايران.

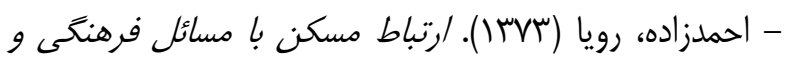
اجتماعى. تهران: وزارت فرهنى و ارشاد اسلامى، معاون

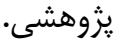

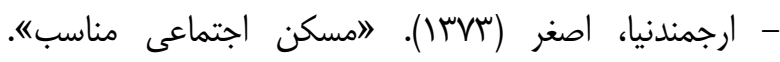

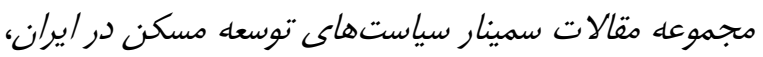

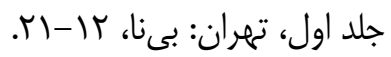

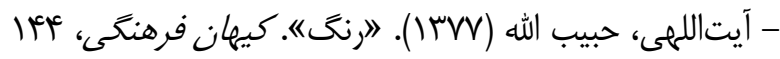
.r-1:(1)

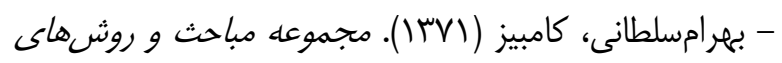

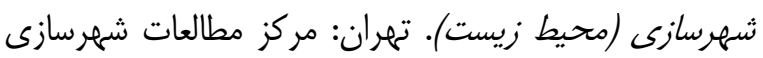
و معمارى ايران.

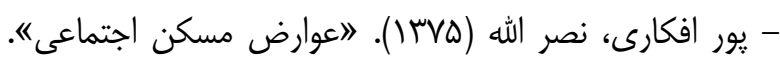

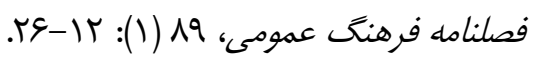

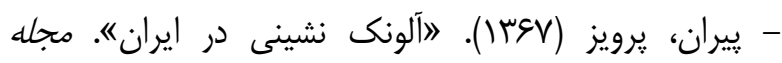

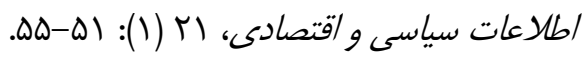

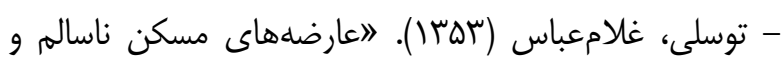

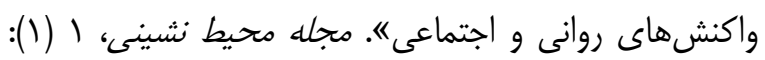
$8 \wedge-91$ - جيبى، محسن و احمدى، زهرا (سلّا ). الأمين مسكن، ايجاد

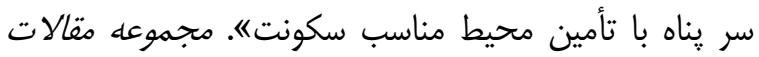
سمينار سياستهاى توسعه مسكن در /يران، جلد اول، تهران:

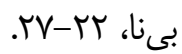

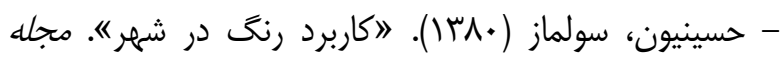

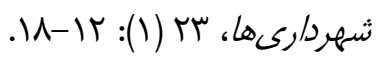

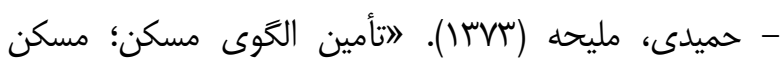
حداقل در الخوى فضاى شهرى و عمومى"، خلاصه مقالات دومين سمينار توسعه مسكن در /يران، جلد اول، تهران: بـى إنا،

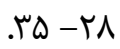

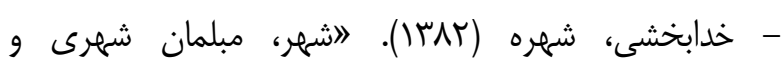

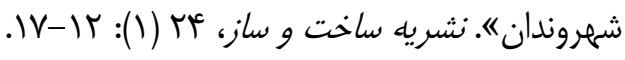

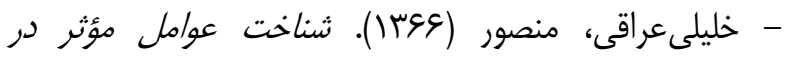
كسترش بعرويه شهر تهران. تهران: انتشارات دانشكاه تهران.

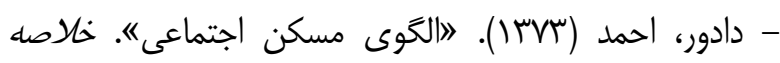

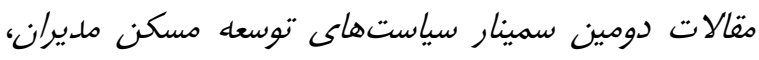
جلد اول، تهران: بىنا، وس-זّأ. 
- Feeney, F \& Weir, A (1973). The Prevention and Control of Robbery: The Response of the Police and Other Agencies to Robbery. CA: University of California.

- Freedman, J.L (1972). "The Effect of Population Density on Humans". Journal of Experimental Ssocial Psychology، 8(1): 528538.

- Janice Bastlin, N \&. Foley, C M (1988). "The Defensible Space Model of Fear and Elderly Public Housing Residents". Journal of Environment and Behavior, 20(1): 50-74.

- Marsella, A.J (1973). "The Effect of Dwelling Density on Mental Disorders in Filipino Men". Journal of Health and Social Behavior,11(2): 280-298.

- Van Der Voordt, D. J. M (1988). Spatial Analysis of Crime and Anxiety - Research Data from the Netherlands and Implications for Design. London: E. \& F. N. Spon.

$$
\text { ج. سايتهاى اينترنتى }
$$

- www.Fekreno.org (Last Revised: 2020)

- www.Healing.about .com (Last Revised: 2020)

- www.Oselink.com (Last Revised: 2020)

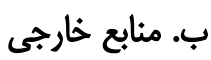

- Altman, I (1971). "The Environmental and Social Behavior". Journal of Applied Social Psychology, 1(2): 60-72.

- Bexter, JC \& Deanovich, B.S (1970). "Anxiety Arousing Effects of Inappropriate Crowding". Journal of Consulting and Clinical Psychology, 35 (2):174- 189.

- Booth, A (1981). "The Built Environment as a Crime Deterrent: Reexamination of Defensible Space”. Journal of Criminology, 18 (2): 557570.

- Conway, D (1974). Social Science and Design. Washington D.C: American Institute of Architects.

- Cunnen, J. M. L (1990). "The Light Solution to Crime: Lighting Makes Life Secure". Lighting Design and Application, 20 (1): 16-17.

- Desor, A (1972). "Toward a Psychological Theory of Crowding". Journal of Personality and Social Psychology, 21(2):

- Edney, J (1972). "Place and Space: The Effects of Experience with a Physical Local". Journal of Experimental Social Psychology, 8(2): 


\section{References}

- Ahmad Zadeh, R (1994). The Relationship of House with social And Cultural Problems. Tehran: Ershad Ministry. (Persian)

- Altman, I (1971). "The Environmental and Social Behavior". Journal of Applied Social Psychology, 1(2): 60-72.

- Arjmand Nia, A (1994). Social House. Vol 1, Tehran: N.P., 12-21. (Persian)

- Ayatollahi, H (1998). Color. Keyhan Farhangi Magazine, 144 (1): 1-2. (Persian)

- Bahram Soltani, K (1992). The Methods of City Building. Tehran: Shahrsazi Center. (Persian)

- Bexter, JC \& Deanovich, B.S (1970). "Anxiety Arousing Effects of Inappropriate Crowding". Journal of Consulting and Clinical Psychology, 35 (2):174- 189.

- Booth, A (1981). "The Built Environment as a Crime Deterrent: Reexamination of Defensible Space". Journal of Criminology, 18 (2): 557570.

- Conway, D (1974). Social Science and Design. Washington D.C: American Institute of Architects.

- Cunnen, J. M. L (1990). "The Light Solution to Crime: Lighting Makes Life Secure". Lighting Design and Application, 20 (1): 16-17.

- Dadvar, A (1994). Social Houses. Vol 1, Tehran: N.P., 36-42. (Persian)

- Delpazir, J (1998). Marginal Housing. Journal of Housing and Revelation, 83 (1): 25-30. (Persian)

- Desor, A (1972). "Toward a Psychological Theory of Crowding". Journal of Personality and Social Psychology, 21(2):

- Diba, D (2005). Cultures in Architecture. Hamsahri Magazine, 766 (1): 15-21. (Persian)
- Dikenz, P (1998). Municipal Sociology. Translated by Hussein Bahre Varan, Tehran: Qods Press. (Persian)

- Edney, J (1972). "Place and Space: The Effects of Experience with a Physical Local". Journal of Experimental Social Psychology, 8(2):

- Feeney, F \& Weir, A (1973). The Prevention and Control of Robbery: The Response of the Police and Other Agencies to Robbery. CA: University of California.

- Freedman, J.L (1972). "The Effect of Population Density on Humans". Journal of Experimental Ssocial Psychology، 8(1): 528538.

- Hamidi, M (1994). Providing House in Public Atmosphere. Vol 1, Tehran: N.P., 28-35. (Persian)

- Hekmati, J (1999). The Role of Greenbelt in Decreasing Audio Pollutions in Cities. Tehran: Iran Press. (Persian)

- Hidaki, Sh (1998). Company of Colors. Translated by Faryad Dehdashti, Tehran: Karang Press. (Persian)

- Hoseinioun, S (2001). The Function of Color in City. Shahrdari Magazine, 23 (1): 12-18. (Persian)

- Janice Bastlin, N \&. Foley, C M (1988). "The Defensible Space Model of Fear and Elderly Public Housing Residents". Journal of Environment and Behavior, 20(1): 50-74.

- Jibi, M \& Ahmadi, Z (1994). Providing House. Vol 1, Tehran: N.P., 22-27. (Persian)

- Kaveh, Sh (2002). Color Therapy. Green in Green Magazine, 21 (1): 18-25. (Persian) 
- Khalili Araghi, am (1987). Important Factors of Tehran Sprawl. Tehran: University of Tehran Press. (Persian)

- Khoda Bakhshi, SH (2003). City and Citizens. Journal of Sakhto Saz, 24 (1): 12-17. (Persian)

- Mahjour, F (1994). Suitable Houses. Vol 2, Tehran: N.P., 27-33. (Persian)

- Marsella, A.J (1973). "The Effect of Dwelling Density on Mental Disorders in Filipino Men". Journal of Health and Social Behavior,11(2): 280-298.

- Mirza Aghai, H (2005). Dwelling, Accountability and Calmness in Life. Tehran: Fekre No Press. (Persian)

- Mohseni, M (2008). Responses to Violence. Tehran: Ganj Danesh Press. (Persian)

- Mortezei, F (2000). Planning Furniture of Streets. Shahrdari Magazine, 17 (1): 25-32. (Persian)

- Mozayani, M (1996). Municipal aesthetics and Culture. Journal of Public Culture, 89 (1): 64-65. (Persian)
- Noghre Kar, AH (1996). Preserving Cultural Values in Architecture. Journal of Public Culture, 89 (1): 25-32. (Persian)

- Piran, P (1988). Allonak Neshini. Political and Economic information Magazine, 21 (1): 51-55. (Persian)

- Pour Afkari, N (1996). The problems of Social Houses. Journal of Public Culture, 89 (1): 12-26. (Persian)

- Seifo Dini, F (1994). At Least Housing. Vol 1, Tehran: N.P., 43- 49. (Persian)

- Shahzad, N (2001). Dejection for Apartment Dwellers. Shahrdari Magazine, 34 (1): 25-32. (Persian)

- Shia, E (1994). Looking for Cultural Traditions in New Dwellings Area. Vol 2, Tehran: N.P., 21-26. (Persian)

- Tavassoli, QA (1974). The problems of Unsuitable Houses. Mohit Neshini Magazine. 1 (1): 61-68. (Persian)

- Van Der Voordt, D. J. M (1988). Spatial Analysis of Crime and Anxiety - Research Data from the Netherlands and Implications for Design. London: E. \& F. N. Spon. 